\title{
CONSIDERACIONES SOBRE ASENTAMIENTOS RURALES Y CERÁMICAS ORIENTALIZANTES EN LA CAMPIÑA GADITANA
}

\author{
CONSIDERATION ON RURAL SETTLEMENTS AND ORIENTALISING \\ POTTERY IN THE CADIZ COUNTRYSIDE
}

\author{
por \\ DIEGO RUIZ MATA* \\ ROSALÍA GONZÁLEZ RODRÍGUEZ**
}

RESUMEN Se analizan los resultados de las intervenciones arqueológicas realizadas en los últimos años en dos establecimientos indígenas protohistóricos de la zona noroccidental gaditana: "Vaina" (El Puerto de Santa María) y "El Trobal" (Jerez de la Frontera). Su estudio sirve de pretexto para reflexionar, de modo muy general, sobre dos temas que se han considerado importantes en el análisis de la fase orientalizante en Andalucía Occidental: el urbanismo y la cerámica a torno.

ABSTRACT The conclusions of recent archaeological interventions in "Vaina" (El Puerto de Santa María) and
"El Trobal" (Jerez de la Frontera), two proto-historic indigenous settelements in northwest Cádiz,
are analysed and used as a pretext to cast a light, in a broad sense, upon two important issues
concerning the orientalizing period in western Andalucía: the urban development and wheel pottery.

I. El presente trabajo tiene como objetivos analizar las características de varios asentamientos protohistóricos, excavados parcialmente en estos últimos años en la campiña occidental gaditana, y sus tipos cerámicos, que nos sirven de pretexto para abordar los problemas concernientes al origen del urbanismo, de las técnicas y conceptos espaciales semitas y su implantación en el medio indígena, y de la vajilla cerámica del siglo VII y comienzos del VI a.n.e.

La primera hipótesis que aquí se mantiene es que el proceso hacia el urbanismo, entendido como emulación de técnicas y espacios fenicios por parte de la población indígena, constituyó un problema complejo en la bahía gaditana, y en general en el Bajo Guadalquivir, y que no afectó por igual ni al mismo tiempo a todos los establecimientos indígenas, que se servían para su cobijo y organización de sus actividades socioeconómicas de otros modelos constructivos y espaciales. De modo más rápido tuvo lugar en los núcleos indígenas que constituían las sedes de las jefaturas locales, por necesidades también socioeconómicas, o en los centros

\footnotetext{
* Universidad de Cádiz.

** Museo Arqueológico de Jerez de la Frontera.
} 
fenicios del interior como apoyo en su estrategia expansiva comercial. La ciudad implica los reflejos de nuevas situaciones creadas en el proceso interactivo entre fenicios e indígenas, que no acaecieron al mismo tiempo en el Bajo Guadalquivir. Hasta fines del siglo VII/comienzos del VI a.n.e. se advierten en la campiña gaditana asentamientos constituidos por cabañas, según esquemas ancestrales desde la Edad del Cobre. No parece correcta, pues, la idea de un proceso lineal y sincrónico de integración y de cambio de los antiguos hábitats por los de un modelo de planificación más compleja al modo oriental.

De otra parte, como segunda hipótesis de este trabajo, la vajilla cerámica fenicia no fue acogida, en todo su repertorio formal, entre la población indígena. Su cerámica permaneció durante el siglo VII a.n.e. en una proporción más o menos relevante, dependiendo del grado de integración, y sólo demandaron los vasos a torno que satisfacían a sus necesidades.

Es el caso de la "cerámica gris", que prácticamente constituyó el mayor porcentaje de la demanda indígena en cuanto a las formas abiertas, en detrimento de las de engobe rojo, características de los asentamientos fenicios. No puede construirse una secuencia lineal y generalizada para un espacio tan vasto y complejo, como es el Bajo Guadalquivir. Los matices, en este caso, son indicios evidentes de los grados de los procesos de integración.

Las cuestiones que aquí planteamos, entre otras, son que el concepto tradicional de "época o fase orientalizante" como aceptación incondicional, por parte de la población indígena, de los elementos culturales fenicios debe ponerse en entredicho. El término de "colonización" fenicia con el concepto que implica de marcar diferencias categóricas estrictas entre colonizador y colonizado -o "sometimiento resignado"-, no es lo que sugiere el registro arqueológico. Somos conscientes que el abordaje de estos problemas nos conduce directamente a Tartesos, tradicionalmente considerada como culminación de la vida urbana en toda su complejidad y reflejo de los aportes culturales fenicios.

II. En realidad, para la verificación de estas hipótesis, contamos con muy pocos datos, al menos en el aspecto urbano, esparcidos irregularmente en un ámbito tan amplio. Nos referiremos sólo a los trabajos que han aportado información suficiente de poblados del Bronce final y de época orientalizante.

La Cádiz de época arcaica, que debió servir de modelo para la expresión del urbanismo en el Bajo Guadalquivir, no ha aportado aún ningún dato de interés, salvo unos cuantos restos de muros muy destruidos, del siglo VII o VI a.n.e., en el barrio de Santa María -según nos informan amablemente sus excavadores-, y se desconoce incluso el emplazamiento de la antigua ciudad. Las prospecciones realizadas hasta el momento en el casco antiguo han resultado infructuosas para su localización. Son por ahora las escasas fuentes, tardías, las predominantes en el sentido histórico y función de la Cádiz arcaica, que aún no han tenido confirmación. Lo mismo puede decirse de Mesas de Asta, una ciudad importante al pié de un estero a juzgar por la envergadura de su necrópolis protohistórica, con la diferencia respecto a Cádiz que aquí si se conoce el emplazamiento de la ciudad indígena. Las excavaciones efectuadas en las décadas de los años cuarenta y cincuenta proporcionaron un conjunto de cerámicas protohistóricas de gran calidad, asociadas a restos de cabañas en algún caso (Esteve, 1945, 1950, 1962 y 1969). El único establecimiento gaditano que ofrece datos de importancia es el Castillo de Doña Blanca (en adelante $\mathrm{CDB}$ ), una ciudad fundada por los fenicios en la primera mitad del siglo VIII a.n.e. (Ruiz Mata, 1988, 1992, 1993 y 1993-b). Las excavaciones, hasta ahora efectuadas, han exhumado restos de la antigua muralla y de un sector de viviendas del siglo VIII a.n.e., restos de habitaciones de los siglos VII y VI a.n.e., fortificaciones de los siglos V y III a.n.e. y amplios espacios con viviendas y zonas artesanales de los siglos IV y III a.n.e. Se trata de una ciudad amurallada, precedida de un foso en su lado norte, desde sus comienzos, en cuya base no se hallan restos de las cabañas indígenas del Bronce final, situadas en otro lugar de la sierra, denominado Las Cumbres, próximo al CDB. En la campiña gaditana se han excavado cabañas indígenas de los siglos VIII a comienzos del VI a.n.e., como son los casos de Campillo, Vaina -en El Puerto de Santa María- y El Trobal, en Jerez de la Frontera, que son objeto de este estudio. 
En la provincia de Sevilla, las perspectivas no son mejores. El poblado de El Carambolo, quizás el primero analizado con cierto rigor, proporcionó los primeros datos de interés. De su fase antigua prefenicia sólo se conoce el que su excavador denominó "fondo de cabaña", y de épocas orientalizante y turdetana el "poblado bajo" (Carriazo, 1969, 1973 y 1978). En este último se excavaron aproximadamente 400 metros cuadrados, una actuación inusual para la época -entre 1958 y 1961-, que podrían haber suministrado datos más precisos sobre el proceso urbano e histórico del Bajo Guadalquivir. De su urbanismo quedan restos de edificaciones superpuestas, poco aclaratorias para determinar modelos de estructuras, y más se parecen a un laberinto sin orden ni concierto que a unos restos superpuestos de edificios desde fines del siglo VIII/comienzos del VII a.n.e. El voluminoso libro publicado sobre las excavaciones constituye más bien una suma de datos, imprecisos, nunca explicados en detalles, y de difícil entendimiento por más voluntad que el lector ponga en su interpretación. En las cerámicas sucede lo mismo: series de tipos cerámicos, básicamente los del "fondo de cabaña", y muy poco de los siglos posteriores, que aún están por estudiar y publicar. Si para la época de su hallazgo y excavación, El Carambolo significó un hito básico en el conocimiento de la protohistoria andaluza, y aún es valorado en su exacta medida, en la actualidad es un marasmo que precisa de una profunda disección y, desde luego, de la publicación íntegra de sus resultados.

La esperanza de desplegar un proyecto sistemático de investigación a largo plazo se centró durante un tiempo breve en el asentamiento del Cerro Macareno. En gran parte se destruyó sin piedad, e impunemente, en los primeros años de la década de los setenta, pues de las 5 Ha que debía tener en origen, 4 de ellas fueron arrasadas por las palas mecánicas para la obtención de grava para la construcción. Más tarde, las excavaciones -en 1974- que comenzaron con un espíritu de trabajo interuniversitario y sistemático, quedaron pronto aparcadas. Se han excavado sólo unas pocas estratigrafías de escasa extensión, se efectuó una limpieza de perfil (Martín de la Cruz, 1976), y en extensión se exhumaron varios hornos de los siglos V y IV a.n.e. (Fernández Gómez y otros, 1979). De todo ello queda una estratigrafía, de poco más de $16 \mathrm{~m}$ de extensión, que aún constituye el paradigma de la secuencia protohistórica del bajo Guadalquivir (Pellicer y otros, 1983), y que requiere, como es natural, de verificación en otros puntos y de trabajos de mayor amplitud.

Varias estratigrafías se han realizado en Carmona (Carriazo y Raddatz, 1960; Pellicer y Amores, 1985; Amores y Rodríguez Hidalgo, 1987), Setefilla (Aubet y otros, 1983; Aubet, 1989) y en la propia ciudad de Sevilla (Campos, 1986; Campos y otros, 1988), con objeto de analizar las secuencias culturales de estos asentamientos. Los objetivos en este sentido se han cumplido en parte, pero una estratigrafía de pequeña dimensión no da más de sí que una idea aproximada de la secuencia a través de los restos cerámicos, y con suerte restos de estructuras constructivas que nos aproximan a las técnicas empleadas, pero no a la comprensión del espacio ni a su significado.

Cabe resaltar, por último, en esta provincia, los trabajos realizados en el poblado de Montemolín (Marchena) (Chaves y otros, 1993; Bandera y otros, 1993), de donde proceden varias edificaciones de carácter monumental, de los siglos VII y VI a.n.e., que sugieren claramente la existencia de un núcleo indígena de gran importancia.

Huelva ofrece un panorama más completo para el análisis del proceso del urbanismo en la protohistoria. En el poblado de San Bartolomé en Almonte se excavaron casi una treintena de estructuras de cabañas de los siglos VIII a comienzos del VI a.n.e., de distintos tamaños y funciones, en un área extensa, que ha proporcionado una idea bastante consistente de la concepción de la estructura de un poblado indígena (Ruiz Mata y Fernández Jurado, 1986). Y en la misma época se datan unas viviendas de mineros y metalúrgicos en el Cerro Salomón, de Riotinto (Blanco y otros, 1970), con un sentido constructivo diferente.

Desde 1977 se excava casi ininterrumpidamente en los cabezos de la ciudad de Huelva, mediante trabajos sistemáticos y de urgencia, que han proporcionado numerosa información sobre urbanismo de los siglos VII y VI a.n.e. (Fernández Jurado, 1988-89; García Sanz, 1988-89). 
En la actualidad se conocen amplios repertorios de la cerámica protohistórica, pero faltan estudios detallados monográficos que analicen materiales bien estratificados y de yacimientos bien elegidos que puedan representar las características distintivas de los diferentes núcleos, sobre todo en la época orientalizante.

Uno de nosotros -D.Ruiz Mata- estudió en su tesis doctoral las cerámicas indígenas tartésicas de los siglos IX al VII a.n.e. -que ha presentado una síntesis como ponencia en "Tartessos, 25 años después", celebrado en Jerez de la Frontera en 1993-, estableciendo una tipología y cronología, que ha servido de punto de partida para poner cierto orden en la confusión en que se hallaban. Se han realizado también trabajos sobre las cerámicas decoradas de diseños bruñidos (López Roa, 1977 y 1978) y pintados (Cabrera, 1981; Buero, 1984 y 1987; Ruiz Mata, 1984-85). Las ollas de cocina con decoración digitada, o incisa, han sido también objeto de varios estudios (Pellicer y otros, 1983, 66; Ruiz Mata y Fernández Jurado, 1986, I, 215; Fernández Jurado, 1987; Ladrón de Guevara, 1994). En cuanto a la cerámica fenicia arcaica y fenicia occidental, se han realizado estudios tipológicos de conjunto (Negueruela, 1979-80; Maass-Lindemann, 1986) o de yacimientos concretos, como Toscanos (Schubart y otros, 1969; Schubart y Maass-Lindemann, 1984), Cerro Macareno (Pellicer, 1982) o Huelva (Rufete, 1988-89 y 1989), por citar sólo los más significados. Pero aún faltan por publicar las cerámicas arcaicas de los estratos de base de Morro de Mezquitilla, de los que sólo se conocen unos cuantos tipos (Schubart, 1986) y las del Castillo de Doña Blanca, que constituyen por ahora el conjunto más numeroso y completo del repertorio fenicio occidental, del que sólo se ha publicado una síntesis (Ruiz Mata, 1986 y 1986-b). La publicación de estas cerámicas va a constituir una aportación importante, e imprescindible, para el repertorio fenicio de Occidente, y actualmente se prepara la Memoria científica. Las ánforas del Cerro Macareno han sido objeto de un estudio, pionero en el Bajo Guadalquivir, para abordar los problemas relativos a los envases comerciales y sus cronologías (Pellicer, 1979), pero la excavación de un área tan pequeña tiene siempre sus limitaciones e interrogantes, que requieren contrastación. Se han publicado asimismo las ánforas del Carambolo (Florido, 1985), con la duda sobre la certidumbre de su secuencia, y las del área gaditana (Muñoz Vicente, 1987), sobre todo las de hallazgos submarinos o inciertos.

Las estratigrafías han suministrado asimismo un acopio importante de información para la secuencia protohistórica del Bajo Guadalquivir y para el conocimiento de sus tipos cerámicos. El Carambolo requiere, como se ha indicado, un análisis monográfico que recoja todo el elenco cerámico de la secuencia, pues hasta ahora se ha publicado lo que su excavador consideró más relevante, y según declara "este libro ha tenido una larga elaboración, y debería quedar todavía sobre la mesa, para que su autor pudiera satisfacer el deseo de completar muchas cosas" (Carriazo, 1973, p.11). Sin restar ningún mérito a la publicación, hubiera sido deseable un esfuerzo aún mayor por conocer los aspectos de toda la secuencia, dada la importancia del asentamiento, su extensión excavada y el privilegio de ser el primero que proporcionó en abundancia un conjunto de materiales hasta entonces ni conocidos ni valorados debidamente. Pese al tiempo transcurrido, y a los trabajos realizados en más de treinta años desde su hallazgo, aún merece la pena acometer un estudio intensivo. Desde esa fecha se conocen secuencias en los poblados de Setefilla, Cerro Macareno, Carmona, Sevilla, Lebrija (Caro y otros, 1987), Montemolín, Castillo de Doña Blanca, Tejada la Vieja (Blanco y Rothenberg, 1987; Fernández Jurado, 1987), Cabezo de S. Pedro (Belén y otros, 1977; Blázquez, Ruiz Mata y otros, 1979; Ruiz Mata y otros, 1981) y del Molino del Viento, en Huelva (Fernández Jurado, 1988-89), San Bartolomé en Almonte y Cerro Salomón, por citar también los de mayor relieve y que han constituido la base de la construcción de la secuencia material del Bajo Guadalquivir. Se conocen algunos más aún no publicados o que han proporcionado sólo niveles correspondientes a épocas más concretas.

Todos estos estudios han suministrado una base importante de información general sobre el proceso protohistórico de Andalucía occidental, en cuanto a un criterio tipológico e histórico cultural. Y en este sentido han de valorarse. No obstante, queda aún mucho por conocer, y sobre todo estructurar de modo más preciso 
la tipológia cerámica, sus porcentajes reales de aparición, y no los erróneos que pueden extraerse de un corte estratigráfico, cuya formación se conoce raras veces y el azar puede ser un factor influyente.

Desde el descubrimiento y excavación del "poblado bajo" del Carambolo hasta aquí, que han transcurrido treinta y cinco años, los trabajos efectuados no han sido tantos como pudiera parecer, y siempre los estudiosos de la protohistoria del Bajo Guadalquivir disponemos de los mismos argumentos, los mismos cortes estratigráficos, arrastramos los mismos aciertos y errores, variando de matices, suministrándonos siempre de las mismas fuentes, nunca sometidas a una crítica constructiva, y siempre validándolas en nuestras reconstrucciones sobre la protohistoria. Hacen falta proyectos acertados y continuos, con fundamentos teóricos que los justifiquen, y con ideas precisas sobre los objetivos que se persiguen.

Otra de las deficiencias ha sido, y aún lo es en cierto modo, la escasa atención que se ha prestado al conocimiento del territorio y de la implantación de las ciudades y caserios protohistóricos. En un mapa publicado en las Actas del V Symposium Internacional de Prehistoria Peninsular en 1968, dedicado a Tartessos (Blanco y otros, 1969), ilustrativo en este sentido, se señalaron los yacimientos conocidos por entonces de esa época. Se indicaron sólo trece puntos en Andalucía occidental, comprendiendo la provincia de Córdoba. Otros estudios más recientes recogen un mayor número (Belén y Escacena, 1992, p. 81), que en realidad sólo aumentan el número de asentamientos y no modifican el límite territorial que por entonces se confinó a la "cultura tartésica", y tampoco analizan el concepto de territorio en su significado socioeconómico y político. Se trataba de añadir "asentamientos", sin más, en unos mismos límites territoriales, sin otros objetivos que confeccionar un catálogo cada vez más numeroso.

En estos últimos años ha proliferado en Andalucia occidental la elaboración de cartas arqueólogicas, como catálogo de "yacimientos", que al carecer de objetivos y planteamientos teóricos no ha aportado demasiado para analizar la estructura política del territorio, pues el objetivo no está tanto en la cantidad como en la cualidad de los argumentos. Estos estudios -salvo contadas ocasiones- no se han realizado según un proyecto global y sistemático, sino debidos a la voluntad ocasional y a la oportunidad. Un punto en el mapa es un asentamiento más a engrosar a la lista de los ya conocidos. Ha sido un esfuerzo útil, pero que no satisfacía la demanda de conocimiento histórico, pues el punto lo mismo podía significar una ciudad, una pequeña villa o caserío, en un espacio no explicado con finalidad de determinar territorios políticos. No se contemplaban variables que condujesen a la relación asentamiento-jerarquización-producción-espacio político. Y de aquí se han derivado conclusiones poco acertadas en cuanto al conocimiento de la estructura poblacional y socioeconómica del Bronce Final, y del significado de la presencia/colonización fenicia y los procesos de interacción.

En estos últimos diez años la "carta arqueológica" ha dado paso al "estudio del territorio", con más significado y utilidad científica e histórica. Los mismos elementos, considerados desde otras perspectivas, favorecen la comprensión de su sentido histórico. En la provincia de Huelva se realizan varios proyectos de investigación que comprenden un territorio amplio. Uno de ellos se titula "Proyecto Odiel (Huelva): 3000-1000 a.n.e. Formaciones sociales de transición: Un modelo de análisis histórico para la contrastación del proceso de jerarquización social", en donde el área de análisis elegida es la cuenca del rio Odiel (Nocete y otros, 1993), bajo una metodología guiada por un enfoque materialista histórico. Sobre el II milenio a.n.e. se trabaja desde 1988 en el proyecto "Análisis y definición de los procesos culturales del II milenio a.C. en el Suroeste peninsular", reducido a la sierra onubense, con el objetivo de "definir la ocupación del territorio en base al estudio fundamentalmente de los poblados atendiendo a la organización y articulación del espacio y al análisis de los sistemas sociales y económicos" (Hurtado, 1993). Y desde 1990 se lleva a cabo un proyecto que pretende rellenar el vacío existente del poblamiento de época pospaleolítica hasta momentos históricos, bajo una perspectiva interpretativa y metodológica de la relación entre los sistemas de ocupación y evolución paleogeográfica del medio natural, denominado "Dinámica de asentamientos y evolución de sistemas natura- 
les. La secuencia holocena del litoral y prelitoral entre el Guadiana y el Guadalquivir. Ocupación y territorio en la Tierra Llana de Huelva" (Campos y otros, 1993). En espacios más restringidos, pero con objetivos similares se trabaja en el asentamiento protohistórico de Tejada la Vieja y en su entorno inmediato (García Rincón, 1987).

En el Bajo Guadalquivir, pero en el área occidental de la provincia gaditana, se desarrolla el proyecto "Paleogeografía humana del extremo noroccidental de Cádiz. Los procesos culturales desde el neolítico a época medieval" (González Rodríguez y otros, 1993). Otro de ellos se denomina "La ocupación prehistórica de la campiña litoral y banda atlántica de Cádiz" (Ramos Muñoz y otros, 1993). Y finalmente mencionemos un proyecto, que comenzó recientemente, "Estudio de los procesos sociales y económicos desde la Prehistoria reciente a época medieval del área nororiental de la provincia de Cádiz", del que no se ha publicado aún ningún resultado. Todos ellos, estructurados metodológicamente y a veces con distintas formulaciones teóricas, pueden ofrecer a medio plazo un panorama coherente sobre los conceptos que del territorio gaditano se posee, y una base suficiente para acometer el análisis de los procesos culturales y socioeconómicos. Desde las perspectivas del poblamiento del Bronce final y del período orientalizante, los datos existentes constituyen ya una base cementada que nos ha animado a desarrollar el trabajo que aquí se expone.

\section{MODELOS DE HÁBITATS INDÍGENAS DURANTE LA EDAD DEL COBRE Y BRONCE FINAL}

La actividad investigadora de la Prehistoria reciente en la baja Andalucía se orientó desde el siglo pasado hacia las excavaciones de las necrópolis, que aportaban material más completo y abundante, en detrimento de los poblados, de amortización más costosa, menos espectaculares y en ocasiones de localización más difícil. De modo que a mediados de la década de este siglo se conocían en Andalucía occidental importantes grupos monumentales de enterramientos de la Edad del Cobre, reflejandose en importantes trabajos monográficos (G. y V. Leisner, 1943; Leisner y Cerdán, 1952), pero ni un solo poblado relacionado con ellos excavado en cierta amplitud.

En cuanto al II milenio, el conocimiento de su cultura material era, y sigue siendo, más desconocido (Ruiz Mata, 1994). La escasez de datos se justificaba con la hipótesis de un cambio climático causante de un desastre ecológico que tuvo como consecuencia más inmediata un vacío poblacional. Durante mucho tiempo, el mapa del poblamiento del Bronce Pleno quedaba reducido en Andalucía occidental a unos cuantos puntos de hallazgos muy dispersos. Aún hoy sólo se conocen grupos de enterramientos datados en esta época, la mayoría sin asociación a poblados. No obstante, el pesimismo con que pudiera contemplarse la investigación de estos momentos, se compensa a partir de 1984-85 con una serie de proyectos de investigación que, pese a su andadura reciente, auguran que a medio plazo puede variar notoriamente el conocimiento que hasta ahora se tiene. Nos referimos, como es natural, a los proyectos antes mencionados, que están proporcionando ya resultados, principalmente en la zona de la serranía onubense.

El asentamiento del Cobre de Valencina de la Concepción, próximo a Sevilla, conocido de antiguo por sus estructuras funerarias monumentales (Obermaier, 1919; Carriazo, 1961-62; Collantes, 1969; Fernández Gómez y Ruiz Mata, 1978), podría haber supuesto un gran avance en la investigación sobre la disposición de la estructura de su habitat en uno de los centros más importantes de la zona. Las excavaciones del poblado, que comenzaron en 1971, hasta la actualidad, han significado un desacierto en la dirección metodológica y en los planteamientos sistemáticos. Se ha excavado suficiente y publicado poco, y la labor realizada ha estado siempre a remolque de las excavaciones de urgencia motivada por el crecimiento urbano de la población actual, con numerosas direcciones sin criterios unificados. Es incomprensible que un asentamiento tan importante carezca, que sepamos, de un proyecto sistemático de investigación. 
Los datos dispersos existentes perfilan, en más de $200 \mathrm{Ha}$., una estructura nuclearizada en torno a grupos de cabañas y silos, entre espacios vacíos dedicados probablemente a la horticultura y ganadería, y largas y profundas zanjas para conducciones de agua para el regadio (Ruiz Mata, 1975 y 1983; Fernández Gómez y Oliva, 1985 y 1986).

Modelos de poblados similares debieron ser frecuentes en la campiña de Andalucía occidental, desprovistos de murallas, y la población agrupada en núcleos de cabañas dispersas entre espacios libres dedicadas a actividades productivas agropecuarias. Modelo que continuó durante el Bronce Pleno y Bronce Final.

En la provincia de Cádiz se ha excavado en estos últimos años en los poblados de transición Neolítico/ Cobre de Cantarranas/Las Viñas (El Puerto de Santa María) (Perdigones y otros, 1985; Ruiz Fernández, 1987; Ruiz Gil y Ruiz Fernández, 1987; Ruiz Fernández y Ruiz Gil, 1989) y El Trobal (Jerez de la Frontera) (González Rodríguez, 1987), y en el del Cobre pleno de La Dehesa (El Puerto de Santa María) (Ruiz Mata, 1994-b), junto al establecimiento fenicio del $\mathrm{CDB}$, que han proporcionado datos de interés para el urbanismo del milenio III a.n.e. en la zona.

El primero han proporcionado restos de cabañas y numerosos silos, que a veces sirvieron de enterramientos, como en varios silos de El Trobal. Como no se han publicado los resultados completos de las excavaciones, se desconoce la relación entre ambos elementos y su organización en el poblado, que pueden tener una distribución similar a lo que se conoce de Valencina de la Concepción. El extremo occidental de la Sierra de San Cristóbal se ocupó durante el Cobre pleno, según un modelo que se viene advirtiendo en la campiña gaditana, consistente en la disposición nuclearizada de agrupaciones de cabañas separadas mediante espacios que pudieron tener funciones productivas. Núcleos de ocupación se establecieron en Las Beatillas, junto a los depósitos de agua de la Confederación Hidrográfica del Guadalquivir, La Dehesa, bajo los estratos protohistóricos del Castillo de Doña Blanca y en otro punto cercano. Es probable que todos ellos estuviesen conectados desde un punto de vista de su organización política, a la par que también se advierte una estratigrafía horizontal que habrá de precisarse en futuros trabajos. Un modelo similar al de Valencina y al de Cantarranas/Las Viñas/Base Naval, ha sido en el núcleo de La Dehesa en donde se han realizado excavaciones en cierta extensión (Ruiz Mata, 1994-b). Consta de un conjunto de cabañas, de planta circular, espaciadas, y otros elementos que debieron servir de silos o de pequeños almacenes. Una de las cabañas, de $3.20 \mathrm{~m}$ de diámetro, se excavó parcialmente en la roca, y las paredes se construyeron de elementos vegetales y arcilla apoyados en un zócalo más consistente de pequeños mampuestos. Núcleos así concebidos debieron repertirse por la amplia extensión que debemos considerar el poblado, en donde se integran zonas de cobijo y almacenes o silos y espacios destinados al cultivo y al ganado. Una estructura integradora de habitación y producción, cuya necrópolis común debió situarse, a juzgar por los datos existentes en Las Cumbres, en donde se ubicaron más tarde las tumbas protohistóricas.

No conocemos restos significativos de poblados del Bronce Pleno en la campiña, salvo restos cerámicos recogidos en las prospecciones y la excavación de una cabaña en San Fernando (Ramos Muñoz, 1991). Los estudios realizados en la sierra onubense proporcionan otro modelo, distinto en algunos aspectos, pero que mantienen un concepto similar. El poblado del Trastejón, en la Sierra de Aracena, consiste en la ocupación de dos terrazas de una colina (Hurtado Pérez y García Sanjuan, 1994), con construcciones de mampuestos. Todavía no se han realizado excavaciones en extensión, pero en las zanjas de la terraza superior se hallan muros con disposición oval o concéntrica, de cierre del conjunto, y restos de actividades; en la inferior, dotada quizás de una "muralla", y durante el Bronce pleno, se halló un nivel sin restos constructivos y "con gran cantidad de granos de cebada (hordeum sativum) mezclados con fragmentos de carbón y trigo de dos especies (triticum aestivo/compactum y triticum durum o turgidum), con lo que es posible que este sector del yacimiento se dedicara al almacenamiento ( $y /$ o quizá cultivo) de este cereal" (Hurtado Pérez y García Sanjuan, 1994, p. 246). Estando aún el poblado en proceso de excavación, y en sus comienzos, resulta arriesgado 
definir con certeza la función de ambas terrazas, pero la analítica -potasio y fósforo- realizada de las arcillas de ambas terrazas insinúa una mayor presencia humana y animal en la superior. Quizás fuera ésta el núcleo de habitación y la inferior la de producción agrícola. Si ello es así, las diferencias con los modelos expuestos no parecen tan sustanciales, salvo en las técnicas constructivas.

Al margen de las cabañas individualizadas -caso, como ejemplo, del Carambolo-, o halladas parcialmente en cortes estratigráficos, no disponemos de la visión de la estructura de un asentamiento de un poblado del Bronce Final, salvo en el caso de San Bartolomé, en Almonte (Huelva), en donde se han realizado excavaciones en extensión, que proporcionan una idea más certera de la concepción de un hábitat indígena protohistórico (Ruiz Mata y Fernández Jurado, 1986).

La población se halla repartida en cuatro altozanos de escasa altura, atravesados por el arroyo de San Bartolomé, seco en la actualidad, que debió tener un cauce más amplio y con agua.

Los hallazgos se reparten en torno a unas $40 \mathrm{Ha}$., por donde se distribuyen núcleos con viviendas y estructuras que sirvieron de almacenes y de talleres metalúrgicos, entre espacios amplios libres de ocupación. Un modelo concordante con los tradicionales en el Bajo Guadalquivir desde la época de transición Neolítico/ Cobre, que perduró hasta fines del siglo VII/comienzos del VI a.n.e. Este poblado ofrece también una clara estratificación horizontal, desde fines del siglo IX hasta los comienzos del VI a.n.e., y en él no se perciben modificaciones ni en los aspectos conceptuales de la distribución del espacio ni en los técnicos, como se verá más adelante en los asentamientos gaditanos. Es el modelo de habitat que hallaron los fenicios en sus primeras arribadas al Bajo Guadalquivir, que no necesariamente implica una cultura poco compleja, ni excluivamente de carácter aldeano (G. Wagner, 1992), si estimamos la aldea como "pueblo de corto vecindario y, por lo común, sin jurisdicción propia" (según se define en el Diccionario de la Lengua Española). Considerados estos asentamientos de modo aislado y desde su base económica agropecuaria, es probable que se llegue a esta conclusión, pero si se analizan en un contexto territorial más amplio, estructurado políticamente, como es el caso del Bajo Guadalquivir en donde se efectúan investigaciones territoriales para analizar estos aspectos, la visión es bien distinta. Se advierten grandes núcleos, tal vez centros de las jefaturas locales, y asentamientos más pequeños dependientes de aquellos, conformando un amplio territorio tribal con fronteras y organización social más compleja. Es preciso insistir en estudios de territorio con carácter intensivo, entre cuyas variables se cuente la dispersión de los hallazgos que nos aproxime a la dimensión de los asentamientos, pues como se dijo con anterioridad, no basta sólo su delimitación con punto en un mapa.

\section{LOS PRIMEROS VESTIGIOS DE URBANISMO FENICIO COMO MODELOS EN EL MUNDO INDÍGENA}

Se considera que el urbanismo es uno de los rasgos definitorios de civilización y de complejidad social, el escalón más alto que separa la barbarie de lo civilizado, y que justo el período orientalizante peninsular se caracteriza por el modelo de vida urbano y de la ciudad. Es más, se llega a afirmar que "el paso definitivo -y decisivo- entre lo que llamamos Prehistoria y la Historia, estriba en la configuración, o el comienzo de ella, de la estructura urbana..." (Bendala, 1989, p.130). Este cambio fue debido a los influjos fenicios, sin explicar la mayoría de las veces las razones que lo motivaron y sus consecuencias en las nuevas estructuras socioeconómicas. Todo ello requiere un análisis profundo y detenido, por no ser tan simple su explicación, que no vamos a efectuar aquí, sino considerar la introducción de los modelos fenicios y su implantación en el medio indígena, sin responder a las cuestiones esenciales. Partimos de la tesis que con anterioridad a la presencia fenicia en las costas meridionales, se advierte un territorio indígena políticamente estructurado y una sociedad compleja, y que los cambios producidos en la conversión de las cabañas en viviendas de estruc- 
tura y técnica fenicias no se llevó a cabo por igual, ni al mismo tiempo, en el Bajo Guadalquivir; sólo los centros indígenas, sedes del poder político, adoptaron nuevos modelos de hábitats por razones también políticas y socioeconómicas. Ello no implicó la adopción de este modelo de modo generalizado.

Lo que consideramos ciudad fenicia occidental está aún por investigar -el caso de Cádiz, por ejemplo-, y lo que poseemos es una amalgama, tampoco bien discriminada, de asentamientos de distintos tamaños y funcionalidades diferentes. A todos ellos los consideramos colonias, cuando en realidad son en la mayoría de los casos factorías o enclaves comerciales más o menos importantes, que sustentaban una población a veces poco numerosa, que no requerían de estructuras de significado político. En las conocidas no se han registrado edificios públicos ni viviendas que pudieran haber tenido la función de un palacio, sino simples casas de varias habitaciones, con espacios cuadrangulares o rectangulares, construidas de mamposteria y arcillas. Los restos de murallas conocidas, a excepción de la del CDB, son de una fase relativamente tardía -caso de Tejada la Vieja, del siglo VII a.n.e. No conocemos, pues, aún qué modelo de ciudad adoptaron los poblados indígenas.

$\mathrm{Al}$ margen de los restos de viviendas, que poco dicen del ordenamiento urbano, las estructuras conocidas de época arcaica se reducen a unos cuantos ejemplos. En cuanto a sistemas defensivos, el Castillo de Doña Blanca ha proporcionado, en un pequeño corte de $2 \mathrm{~m}$ de anchura, los restos de la muralla del siglo VIII a.n.e. -conservada en más de $5 \mathrm{~m}$ de altura-, precedida de un foso, de $20 \mathrm{~m}$ de anchura y casi 2 de profundidad, construida de mampuestos irregulares y apoyada en un zócalo amplio, con las paredes revestidas de arcilla. Restos de una probable muralla se hallaron en otro sector del poblado, y sugiere una disposición de casernas. Poco posterior debe ser el foso con que debió protegerse el asentamiento de Toscanos (Niemeyer, 1979, 1982, 1986).

Modelos de vivienda, en cuanto a su disposición interna, proceden de los estratos inferiores de Morro de Mezquitilla (Schubart, 1979, 1984, 1985), Chorreras (Aubet, 1974; Aubet y otros, 1979) y CDB. Poseen varias habitaciones, carecen al parecer de patios interiores, y en varias de ellas se han hallado hogares y hornos de pan. Están construidas con paredes de mampuestos, y de adobe o tapial en ocasiones, enfoscadas de arcilla y pintadas con cal. Se distribuyen en manzanas, separadas por calles y plazas -Morro de Mezquitilla y Chorreras-, o en disposición aterrazada, separadas por una calle estrecha -Castillo de Doña Blanca-.

El carácter comercial de estos asentamientos parece evidente. En este sentido cabe interpretar, como almacenes, unas estructuras, de comienzos del siglo VII a.n.e., procedentes de Toscanos (Schubart y MaassLindeman, 1984; Niemeyer, 1986). Se trata de una estructura de tres naves alargadas -de casi $15 \mathrm{~m}$ de longitud-, en cuyo interior se hallaron ánforas y vasijas de transporte para almacenamiento. Un modelo similar a los hallados en Hazor o Mozia. De época más tardía se ha excavado la factoría de Abul, en el valle bajo del Sado (Alcáçer do Sal), que sirve de modelo para conocer cómo debían ser estos pequeños establecimientos comerciales (Mayet y Tavares da Silva, 1992 y 1993), que proliferaron en la costa en zonas próximas a poblados indígenas. Se trata de una estructura cuadrangular de escasa extensión -de poco más de 500 metros cuadrados-, que ha tenido remodelaciones a lo largo del siglo VII y comienzos del VI a.n.e, cerrada por un muro amplio o muralla, a cuya pared interior se adosan habitaciones y almacenes, en torno a un patio central.

En las técnicas constructivas se empleó preferentemente la mampostería, y ocasionalmente muros de adobes o tapial. Los sillares se utilizaron en las esquinas de varias habitaciones, como atestiguan las viviendas arcaicas del Castillo de Doña Blanca, en las jambas de algunas puertas, o en la construcción de muros recios de murallas o de contención, cuyo ejemplo prácticamente único es el muro del Cabezo de San Pedro, en Huelva (Ruiz Mata y otros, 1981). Los enfoscados suelen hacerse de arcilla, y de tierra batida los suelos, a veces con lechadas de cal y almagra, mientras que las paredes se pintaron con cal. No conocemos con exactitud la fabricación de las techumbres, pero probablemente se construyeron mediante un armazón de vigas de madera y tablas, como en Toscanos (Schubart y Maass -Lindemann, 1984), que servían de asiento a una estructura vegetal. 
Estos son los elementos, por ahora conocidos de época arcaica, que debieron constituir los modelos sobre los que los poblados indígenas efectuaron sus cambios urbanos y constructivos: asentamiento amurallado, fosos defensivos, viviendas de varias habitaciones, agrupadas en ínsulas separadas mediante calles, callejones o plazas, estructuras tripartitas como almacenes, el empleo del muro de mamposteria, de adobes y tapial y la cal y almagra como elementos decorativos.

Durante el siglo VII a.n.e. se advierten numerosos ejemplos de asentamientos que emplearon estos elementos, que no constituyen el objeto de este estudio. Consideramos sólo aquellos aspectos que favorecen la hipótesis, enunciada al principio, de que el urbanismo arraigó primero en los centros en donde los fenicios tenían más intereses comerciales y en las sedes de las jefaturas indígenas. Ejemplo de lo primero puede ser El Carambolo, en sus estratos inferiores, de donde proceden un número considerable de ánforas y cerámicas típicas fenicias de engobe rojo del siglo VIII a.n.e. (Ruiz Mata, 1986), que no son frecuentes en los lugares de poco arraigo fenicio. Entre las ciudades indígenas, que durante el siglo VII a.n.e. adoptaron las fórmulas urbanas fenicias, se halla Huelva (García Sanz, 1988-89), Tejada la Vieja (Fernández Jurado, 1987) y Montemolín (Chaves y otros, 1993), por citar las más conocidas. En este último yacimiento se han hallado varios edificios superpuestos, de grandes dimensiones, desde una gran construcción ovalada -17 x 13 m- a construcciones compartimentadas en espacios cuadrangulares y rectangulares complejas, que denotan la existencia de edificios públicos en los siglos VII y VI a.n.e. En el siglo VII a.n.e se construyó el edificio C, que ocupa una superficie de 310 metros cuadrados, y una planta rectangular de $14.5 \times 14.5 \mathrm{~m}$, estructurado en torno a un patio abierto. Y el edificio D, del siglo VI a.n.e., es algo menor, pero de estructura también compleja.

Si es ésta la situación, en la adopción de modelos fenicios, se constata que existieron en el mismo tiempo asentamientos indígenas que continuaron sirviéndose de los mismos habitats arcaicos, adoptando en cambio, desde el punto de vista de los materiales, ciertas formas de la vajilla cerámica orientalizante. Consideramos este hecho de gran importancia en cuanto a la distinción neta de los centros de poder y a la relación campo y "ciudad", como consecuencia del auge de los centros indígenas producido por el incremento de la producción $y$ de su control con un sentido ya comercial.

\section{LOS ASENTAMIENTOS INDÍGENAS RURALES}

En el análisis del poblamiento que se lleva a cabo en la zona occidental de la campiña gaditana, entre los rios Guadalete y Guadalquivir, se han reconocido varios establecimientos del siglo VII a.n.e. que muestran una estructuración arcaica de su habitat. Como venimos procediendo nos referiremos sólo a los casos en los que se ha efectuado alguna intervención arqueológica: Campillo, Las Beatillas, El Trobal y Vaina.

\section{IV.1. El poblado de Campillo: un ejemplo de los primeros contactos de fenicios e indígenas}

No es nuestra intención abordar el problema de la fecha fundacional de Cádiz, ni siquiera extendernos en la época de los primeros intercambios, pero en un estudio de síntesis reciente sobre la formación de los estados en el Mediterráneo occidental, y en relación con la denominada "precolonización fenicia", de fecha anterior a la constatada en el Castillo de Doña Blanca, que ofrece la documentación más antigua para la bahía gaditana, se argumenta "que los posibles rastros del llamado periodo precolonial no pueden hallarse en el interior del Castillo (se refiere al CDB), sino en el hábitat indígena del Bronce Final situado en sus inmediaciones. Tal vez cuando se lleve a cabo la excavación de ese poblado se encuentren las claves necesarias para 
zanjar la discusión sobre la precolonización fenicia" (Plácido Suárez, Alvar Ezquerra y González Wagner, 1991, p.157).

El Castillo de Doña Blanca, tal como ahora se contempla en toda su extensión -en torno a $5 \mathrm{Ha}$ - durante el siglo VIII a.n.e., debió ser de proporciones más modestas en sus comiènzos, y es probable que ahí se hallen las claves de los primeros vestigios. Y de otra parte las excavaciones realizadas en el poblado de San Bartolomé en Almonte, en donde se han exhumado cabañas al parecer prefenicias, por su tipología cerámica, y otras con sólo varios materiales de importación, no sugieren que éstos sean más antiguos que los hallados en el CDB (Ruiz Mata y Fernández Jurado, 1986). Lo mismo sucedió en los estratos del Bronce Final del Cabezo de San Pedro (Ruiz Mata y otros, fig.41:153), de donde procede una botellita o ampolla de engobe rojo. Sólo en el asentamiento de Peñalosa se tiene constancia en la aparición en un fondo de cabaña de una copa de engobe rojo, que puede datarse muy a comienzos del siglo VIII a.n.e. (Fernández Jurado y otros, 1990), documentadas en la estratigrafía de Tiro (Bikai, 1978, 30-3). Copas similares se han hallado dispersas en la zona de los esteros próxima a las Mesas de Asta, que no se hallan, sin embargo presentes hasta ahora, en los estratos más antiguos del CDB. El espacio, pues, de la precolonización, puede reducirse a unos 20 ó 25 años, o poco más. Lo cual constituye un tiempo suficiente para un reconocimiento de las posibilidades de asentamientos e iniciar unos primeros contactos. No es preciso, ni además creible, que hayan hecho falta 300 años, desde 1100 a 800/775 a.n.e., en que empieza a haber una documentacion sustanciosa, para que los fenicios se decidiesen a establecerse en las costa meridional de la Península.

El caso de Campillo es el de un poblado del Bronce Final indígena, próximo al CDB, en donde se perciben rastros de materiales arcaicos fenicios de carácter de lujo, en un contexto típico de material indígena prefenicio (Ruiz Mata, 1994-b). Se asienta junto al arroyo del mismo nombre, que debió tener más caudal por aquella época, y las cabañas excavadas y prospectadas denotan un modelo similar al más antiguo de La Dehesa, del Cobre Pleno, o al de S.Bartolomé, del Bronce Final. En el denominado fondo I, el material predominante es a mano, con formas típicas del Bronce Final prefenicias, entre las que se hallan un frutero, de pié alargado y acanaladuras, de engobe rojo, fragmentos del cuerpo de un oinocóe y una base, un plato o cuenco de borde muy estrecho, varias copas de decoración polícroma, por el interior y exterior, o de engobe rojo, el borde de un ánfora acaso de vino, un fondo de pátera también de engobe rojo, y el fragmento de una copa de superficies grises de excelente calidad (Ruiz Mata 1994-b, figs.17 y 18). Todos los materiales se documentan en los estratos arcaicos del CDB, de mediados o primera mitad del siglo VIII a.n.e.

Contrastados estos ejemplos, reflejan que el único material por ahora más antiguo se documenta en un fondo de Peñalosa, cerca de Tejada la Vieja, y en varios asentamientos cercanos a Mesas de Asta así como en (González Rodríguez, R. y otros e.p.) la necrópolis protohistórica de esta ciudad. Mas la diferencia cronológica con el material fenicio de Campillo, con formas ya presentes en la ciudad fenicia del CDB, es muy escasa. Hasta el momento es ésta la situación que contesta a la pregunta de la etapa precolonizadora y de los primeros contactos entre fenicios e indígenas. Se trata sólo de baratijas, de cerámicas a torno exóticas, de cierto lujo, y de la introducción del vino y del aceite, además de los productos perecederos que no han llegado hasta nosotros. Sugieren el inicio de unas primeras relaciones, que estableciesen las bases de las redes comerciales y productivas que se desarrollarán más tarde, a partir de finales del siglo VIII a.n.e., y sobre todo durante el siglo VII a.n.e.

\section{IV.2. Asentamientos indígenas del siglo VII a.n.e.}

Son numerosos los asentamientos indígenas del siglo VII a.n.e. que continuaron viviendo según los modelos de hábitats arcaicos, que nunca adoptaron ni los espacios ni las técnicas constructivas fenicias, y muchos de ellos debieron abandonarse en los comienzos del siglo VI a.n.e. 
Las Beatillas se sitúa en el extremo occidental de la Sierra de San Cristóbal, a unos $3 \mathrm{~km}$ de distancia del CDB. Las prospecciones y limpiezas de perfiles efectuadas denotan un hábitat de cabañas, que han suministrado materiales de comienzos del siglo VII a.n.e.(Ruiz Gil y otros, 1990). Las cerámicas a mano indígenas, que constituyen el porcentaje más alto, responden a tipos más evolucionados que los del fondo I de Campillo, y coexisten con productos a torno fenicios bien documentados en el CDB en esta época, reducidos al borde de un ánfora, el borde de un plato gris, un "pithos" con decoración polícroma, un fragmento polícromo y parte de un borde perteneciente a un plato. Pese a la proximidad al CDB ni se adoptaron sus fórmulas urbanas ni el material torneado fenicio es abundante, sino escaso y exótico, en una fecha ya relativamente avanzada.

En El Trobal, en plena campiña jerezana (fig. 1), y con motivo de la apertura de una cantera, se excavó por el procedimiento de urgencia parte de un poblado de transición Neolítico/Cobre (González Rodríguez, 1987), entre cuyos silos y restos de viviendas se detectó y excavó un fondo de cabaña de época orientalizante, perteneciente tal vez a un pequeño asentamiento rural. Materiales superficiales de esta época se recogieron en una extensión más amplia. Su interés reside, además, en que se excavó por completo y ha proporcionado datos sustanciosos para el análisis de los porcentajes cerámicos y su cronología.

Su estructura es de tendencia aproximadamente circular, posee unas dimensiones de $4.20 \times 4.40 \mathrm{~m}$ (fig. 2). Su relleno está constituido por un único estrato arqueológico, grisáceo-castaño, de unos $30 \mathrm{~cm}$ de potencia como promedio, que ha proporcionado un abundante material; bajo él se sitúa un nivel, de arcilla rojiza compacta, mezclada con margas, prácticamente sin material arqueológico, que constituyó el nivel de base y de allanamiento para la construcción de la cabaña. Nos hallamos ante una estructura cerrada con un único nivel de ocupación, que ha proporcionado un nutrido conjunto cerámico y lítico, junto a adobes y fragmentos de carbón.

En cuanto al material cerámico, se han recogido 494 fragmentos, de los cuales 318 corresponden a formas identificadas, que son los que se han considerado para este estudio. El resultado se refleja en las figuras 24 y 25.

En suma, la cerámica a mano, con 137 fragmentos, alcanza el $43,08 \%$ del total, y la torneada supone el $56,92 \%$ y 181 fragmentos.

De la cerámica a mano, el 90,51\% muestra superficies toscas o semicuidadas, mientras que sólo un pequeño porcentaje -9,49\%-son de superficies cuidadas. Aunque no se han establecido aún análisis porcentuales en Campillo, puede afirmarse que la mayoría de la cerámica es de superficies y factura toscas, inversamente a lo que sucede por ejemplo en otros yacimientos del Bronce Final, como El Carambolo (C) o Cabezo de San Pedro (SP). Las formas más cuidadas son las cazuelas (fig. 3: 1-5), aunque sin excesivo tratamiento, y corresponden a una tipología del siglo VII a.n.e. -tipo A.II.b., de Ruiz Mata- (Ruiz Mata, en prensa). Oscilan entre 18 y $20 \mathrm{~cm}$ de diámetro, un rasgo característico de modernidad, y los bordes han perdido las carenas acusadas, propias de momentos más antiguos.

Las formas toscas y semicuidadas corresponden a cuencos y a vasos cerrados. Los cuencos (fig. 3: 6-21) ofrecen diversidad en cuanto a la configuración de sus bordes, profundidades y diámetros -a veces alcanzan $37 \mathrm{~cm}-$, y poseen superficies de coloración acastañada o grisácea, y alisadas, espatuladas o en algún caso bruñidas, advirtiéndose en ocasiones exteriores rugosos e interiores alisados. Parece una constante en los poblados del Bronce Final de la campiña gaditana el empleo de cuencos desde fases antiguas, en contraste de nuevo con otros poblados de la misma época, ya mencionados -SP y C-, en donde son prácticamente inexistentes.

Las formas cerradas son numerosas -91 fragmentos que corresponden al $66,42 \%$ de la cerámica a mano-, entre las que predominan las ollas de cocina (figs. 4 y 5). Generalmente muestran cuellos cortos y cóncavos, cuerpos de tendencia ovoides o globulares y superficies toscas, a veces escobilladas. Los tamaños son variables, y 
en un caso (fig. $5 ; 1$ ) tiene un diámetro de $48 \mathrm{~cm}$, correspondiendo más bien a un recipiente de almacenamiento. Con frecuencia decoran sus hombros mediante impresiones digitadas, y en menor porcentaje con incisiones o ungulaciones (fig. 5: 2 y 15) o mediante decoraciones plásticas, consistentes en cordones de arcilla (fig. 4: 2 y fig. 5: 1 y 19). Son vasos de uso doméstico, como ollas de cocina o de almacenaje, cuyas formas son arcaizantes y las decoraciones son frecuentes desde el siglo VIII a.n.e., aunque es en el siglo VII cuando su uso es más abundante. En ellas se han visto las huellas de influjos exteriores -origen atlántico, indoeuropeo o fenicio-, y según nuestras propias investigaciones son simplemente formas locales del Bronce Final de Andalucía Occidental. No vamos a ocuparnos más espacio sobre este asunto.

Se han hallado fragmentos de vasos de gran capacidad, del tipo "à chardon" (fig. 6: 1-7), frecuentes en el siglo VII a.n.e., que poseen cuellos altos de tendencia acampanada, de superficies alisadas, separados mediante una carena, de cuerpos ovoides sustentados en una solera aplanada. Recubren en ocasiones sus superficies mediante una aguada de almagra poco consistente.

Las asas de los vasos toscos se reducen a pequeños mamelones, a asideros abultados en forma de media luna (fig. 6: 3) o a asas de sección circular (fig. 6: 8).

Los vasos a torno fenicios constituyen más de la mitad -56,92\%- del total computado. Las más frecuentes son las denominadas cerámicas grises: 123 fragmentos, que en porcentajes representan el $67,96 \%$ de la cerámica a torno y casi un $39 \%$ del conjunto total. Constituye la clase cerámica más numerosa aquí y en otros poblados de la misma época. No se trata en realidad de una creación estrictamente fenicia y que la empleen con frecuencia en su repertorio cerámico, sino más bien se realizaron en alfares fenicios para satisfacer la demanda indígena durante los siglos VII y VI a.n.e. (Belén Deamos, 1976; Aranegui, 1975; Rooss, 1982). Es ilustrativo, en este caso, señalar que en los estratos de la segunda mitad del siglo VII a.n.e. del Cerro de la Cabeza (Santiponce, Sevilla), alcanza un $23 \%$ del total de los materiales (Domínguez, Cabrera y Fernández Jurado, 1988, p.173), en Tejada la Vieja, por la misma época, el porcentaje es de un 17 \% (Fernández Jurado, 1986, p.132) y en el Cerro Macareno el cómputo oscila entre un $22.85 \%$ en el primer cuarto del siglo VII a.n.e. y un $16.73 \%$ a fines de ese siglo (Pellicer y otros, 1983, p.78). Porcentajes menores que en la campiña gaditana, compartidos con las cazuelas a mano, pero alto en términos generales y si se comparan con su uso en los asentamientos fenicios.

Responden generalmente a platos o cuencos carenados $-33,15 \%$ de la cerámica a torno- del conjunto de la cerámica gris- (fig. 7 y fig. 8: 1-7), de bordes cortos cóncavos y diámetros que oscilan entre 23 y $30 \mathrm{~cm}$., de superficies no excesivamente cuidadas. Otros tipos son simplemente cuencos (fig. 8: 8-12), de bordes apuntados, que en esta cabaña, y en general en otros asentamientos andaluces, ofrecen un porcentaje de aparición bajo $-3,31 \%$ de la cerámica a torno. Una tercera forma abierta es la pátera, de borde vertical o reentrante y carena acusada que lo separa del cuerpo (fig. 9: 1-4).

Cabe destacar que un gran número de fragmentos ostentan, por su interior, una decoración líneal geométrica, mediante bruñido o acanaladura (fig. 8: 1 y 8; fig. 10), consistente en amplias bandas radiales que limitan líneas en zigzag, paralelas, retículas o en cadenetas, como en las cazuelas indígenas de superficies bruñidas. Tal decoración, sobre cerámica gris, no es desconocida en otros ámbitos andaluces, como en Setefilla (Aubet,1983,p.116), Cabezo de La Esperanza, en Huelva (Belén Deamos, Fernández-Miranda y Garrido Roig, 1977, p.320) y en El Carambolo (Carriazo, 1973, p.558 y fig.448), pero es en el ámbito de la bahía gaditana, como muestra el CDB, en donde tuvo su mayor desarrollo.

Otros vasos a torno, incluyendo a las ánforas, suman 58 fragmentos, lo que supone un $32.04 \%$, que se distribuyen del modo siguiente: 8 fragmentos de ánforas $-4.42 \%-, 33$ de los tipos que genéricamente pudiéramos denominar urnas -18.23\%-, 6 cuencos de diferentes tipos -3.31\%-, y 11 fragmentos de formas diversas. Es decir, se continuó empleando de modo más abundante las ollas y vasos de superficies toscas, mientras que los recipientes a torno que sirvieron para fines similares son más escasos. Lo mismo sucede en cuanto a los 
cuencos a mano y a torno. Las ánforas sólo pueden denotar la existencia de un comercio y demanda de aceite y vino.

Los restos de ánforas corresponden a la forma característica fenicia "de saco" o R-1 (fig. 11), y los bordes son los usuales del siglo VII a.n.e., hallándose repartidas por toda el área de la geografía tartésica y en las zonas en donde los fenicios tuvieron intereses comerciales, tanto por rutas del interior, como las costeras hasta la provenza francesa. Resultaría prolijo extendernos en este punto, que requiere un estudio monográfico sobre una tipología más precisa y análisis de pasta mediante las que pudieran determinarse centros de producción.

Los vasos cerrados, o "pithoi", provistos de asas generalmente geminadas, se han hallado con relativa frecuencia en este fondo cerrado (fig. 12). Poseen cuellos rectos o acampanados, bordes que rematan en una pestaña saliente, y baquetón o arista que los separa de un cuerpo ovoide. El tamaño puede variar, según su uso, y en esta cabaña muestran diámetros de boca entre 17 y $26 \mathrm{~cm}$, siendo más frecuentes los que oscilan entre 17 y $20 \mathrm{~cm}$. Se decoran con frecuencia mediante amplias bandas de pintura rojiza -los más antiguos a veces con engobe- y filetes en negro, sobrepintados en ocasiones sobre el rojo, como una versión occidental del "black on red" (fig. 12: 5,7 y 8). Su área de dispersión es igualmente amplia. Señalaremos sólo que son las mismas formas existentes en el poblado fenicio del CDB, desde comienzos del siglo VII hasta mediados del VI a.n.e., de donde deben proceder los ejemplares de El Trobal.

Los cuencos a torno son escasos (fig. 14: 1,5 y 6), pero significativos, en cuanto se relacionan con formas abundantes y características del siglo VII a.n.e. del CDB. El número 1 de esa figura posee un borde corto y carenado, como rasgo distintivo, y las paredes se recubren de pintura roja por el exterior; los números 5 y 6 son cuencos de bordes rectos o ligeramente inclinados, recubiertos también de pintura roja. Otra forma usual del siglo VII a.n.e. es el plato o cuenco de borde cóncavo (fig. 14: 4), recubierto de pintura roja.

Otras formas son la parte central de un soporte (fig. 14: 8) y el platillo inferior de un quemaperfumes (fig. 14: 2), decorado con pintura roja. Cabe resaltar el fragmento de borde de una lucerna (fig. 14: 7), que es un elemento extraño, como sistema de iluminación, en contextos indígenas y muy frecuente en los asentamientos fenicios, como se ha comprobado en el $\mathrm{CDB}$ con varios centenares de piezas.

Mencionemos, por último, por el arcaismo y la continuidad de tradiciones tecnológicas que supone en un momento tan avanzado, la presencia de 130 objetos píticos tallados, realizados mayoritariamente en sílex, básicamente microlíticos, con escasa evidencia laminar, que corresponden a 125 restos de talla y sólo 5 útiles. En opinión de Ramos Muñoz (1991-b, p.243), a quien se ha cedido su estudio, tales restos, en los que predominan los restos de tallas, unidos a su distribución espacial, sugieren la existencia en el interior de la cabaña de un pequeño taller doméstico, que insinúa a su vez un proceso de decadencia en la talla de industrias líticas.

La distribución del material, que ha sido recogido y estudiado con minuciosidad, sugiere la existencia de actividades definidas en su interior (fig. 15): A) un área de almacenaje para el consumo doméstico, situada en el sector norte, en donde se concentran ollas, vasos, urnas y ánforas; B) área de producción con la localización de un taller lítico para manufacturas de artefactos de uso doméstico; C) área de consumo alimenticio en la zona occidental, si se considera que es aquí en donde se concentran los recipientes abiertos y los restos de un posible hogar. Y puestos a precisar la localización de los objetos, los que se pueden considerar de prestigio cuarzos, Jacintos de Compostela, lucerna, botella o soporte, y metales- se han hallado en la zona Este. Consideremos, finalmente, que prácticamente la totalidad de los materiales se hallaron en los límites de líneas discontinuas que muestra la figura 15 , casi en su interior, debiendo servir las zonas exteriores para otros usos no relacionados con la producción y el consumo.

El poblado de Vaina se halla junto al arroyo del mismo nombre, aproximadamente a $1 \mathrm{~km}$ del de Campillo, en plena campiña portuense (fig. 1). Su descubrimiento tuvo lugar en el curso de la excavación de amplios y profundos canales para la puesta en regadío de la zona, apercibiéndose en sus perfiles estructuras cortadas 
correspondientes a la Edad del Cobre, Bronce Final y época orientalizante. Se recogieron materiales de ellas, pero en una sola se realizó una excavación de urgencia, cortada por la zanja. Se trabajó en una zona relativamente amplia, pero incompleta, que lo mismo puede corresponder a un fondo de cabaña de gran extensión o a un basurero. El caso es que se ha exhumado un conjunto numeroso de materiales del siglo VII/comienzos del VI a.n.e., que refleja claramente, como en el ejemplo anterior, la existencia de hábitats en cabañas en fechas tardías y el grado de adopción del repertorio cerámico fenicio en un ámbito indígena. La comparación y contraste entre El Trobal y Vaina puede resultar ilustrativa. Las ilustraciones muestran la tipología del material, con objeto de abreviar el número de figuras. Advertimos también que, pese a que en estas tablas el material se sitúa en sus correspondientes estratos, que hemos mantenido, en realidad se trata de un solo nivel, y los fragmentos concertaban en muchas ocasiones.

Dadas las características de la zona excavada y la indefinición funcional de la estructura, se trabajó sólo con los materiales que han proporcionado formas y definición tipológica. Se han reconocido 302 formas, de las que $33-10.93 \%$ - corresponden a vasos a mano y 269 -el $89.07 \%$ - a torno. El porcentaje de la cerámica fenicia es aquí aún más numeroso que en la cabaña de El Trobal. En resumen el material ofrece las siguientes características:

- La cerámica a mano (fig. 16) se reparte en 14 cuencos -profundos, semiesféricos y una cazuela (tipo 4)-, 11 copas, de bordes señalados o simples, y sólo 8 ollas, con los bordes que muestran los dibujos. Comparada con el fondo de El Trobal, la reducción de las formas a mano es evidente, y los vasos de almacenaje se sustituyeron evidentemente por los fabricados a torno (figs. 24 y 25).

- Las formas a torno son mayoritarias, pero de ellas sólo 11 - un $4.08 \%$ de la cerámica a torno- corresponden a vasos de engobe rojo (fig. 17), bordes de platos y a cuencos. No se ha podido medir la anchura del borde de ningún plato, pero sus extremos caidos son propios en el CDB de comienzos del siglo VI a.n.e. (Ruiz Mata, 1987, p.304). En El Trobal se halló un solo borde de plato.

- En los cuencos a torno (fig. 17) -8 fragmentos de bordes- se advierten diferentes tipos en cuanto a la estructura de los bordes, decorados casi siempre por el exterior mediante amplias zonas rojas sobrepintadas de filetes negros. Faltan tipos representativos de la primera mitad del siglo VII a.n.e. del CDB.

- Como en El Trobal, la cerámica gris es la que predomina en el repertorio de los vasos abiertos a torno, con 101 fragmentos que representan el 33,44\% sobre el total -en El Trobal, $38.68 \%$-. Se distribuyen entre platos (fig. 18), mayoritariamente de bordes cortos y cóncavos -33 fragmentos y $12,27 \%$ de la cerámica a torno-, cuencos (fig. 19), de tendencia a bordes engrosados - 33 fragmentos, que suponen el $12,27 \%-$, y vasos hondos (fig. 19), de páteras o fuentes, que ofrecen una tipología diversa, tal como se muestra en la figura -20 fragmentos y 7,43 de la cerámica a torno-. La demanda fué, en este poblado, de vasos grises, en detrimento de las páteras y platos de engobe rojo, que son mayoritarios en el CDB.

- Los recipientes de almacenamiento, urnas y "pithoi" (fig. 20), constituyen el $20 \%$ de la producción a torno -18,23 en El Trobal-, con 54 fragmentos de bordes que corresponden a otros tantos vasos. De ellos los más representados son los tipos 2,3 y 4 , y parece que faltan los que ostentan un baquetón en el cuello -tipo 1-. Los tipos 3 y 4 muestran urnas de cuellos abiertos o acampanados, que en el CDB son un signo evidente de modernidad y se datan desde los comienzos del siglo VI a.n.e. Generalmente se decoran con bandas de pintura roja y filetes negros, sin un patrón decorativo evidente.

- Las ánforas son abundantes (fig. 21) -26 fragmentos de bordes, que suponen el $9.66 \%$ de la cerámica a torno. Sin adentrarnos en demasiadas características tipológicas, que están expresadas en la figura, se advierte, al menos en cuanto a la estructura de los bordes, una tipología más amplia. Los bordes y carenas corresponden a ánforas o derivadas de ellas. Destaquemos los bordes del tipo 3 , que son cortos 
y en ángulo con hombros más caidos que los de los tipos más arcaicos, y en el CDB son del siglo VI a.n.e. Y el tipo 10 muestra un borde y hombro no frecuente en estas fechas, pero usual desde el siglo $\mathrm{V}$ a.n.e. El fondo 8 de la figura 22 puede corresponder a un ánfora de época arcaica samia o corintia.

- En este contexto se han hallado unas ollas de superficies más alisadas (fig. 22: 9), de bordes cortos, rectos y exvasados, que ostentan por debajo del cuello líneas incisas. Son tipos iguales a los de los estratos de la primera mitad del siglo VI a.n.e. del CDB (Ruiz Mata, 1987, p.309).

- En cuanto a las decoraciones, véase el gráfico de la figura 23 , que comentamos sucintamente. Las decoraciones bruñidas, que constituyen un porcentaje de $9.8 \%$ del total de la cerámica decorada, y sólo un $2.3 \%$ del conjunto cerámico, se aplica a los interiores de cuencos y copas (fig. 22: 1) o sobre platos grises (fig. 22: 3), siempre en un diseño lineal y reiterativo. Las ollas suelen ostentar, con menos frecuencia, decoraciones digitadas $-7 \%$ y $1.6 \%$ - o incisas $-5.6 \%$ y $1.3 \%$ - (fig. $22: 2,5$ y 6 ). Las cerámicas a torno pintadas y bícromas constituyen los mayores porcentajes, como es natural en un contexto en que el predominio de la vajilla torneada es evidente. A veces los fondos de las ollas de cocina a mano muestran decoraciones incisas o acanaladas (fig. 22: 7). En suma, decoraciones y motivos muy conocidos en el Bajo Guadalquivir, que no aportan más novedad que la perduración de los diseños bruñidos o digitados hasta el siglo VI a.n.e.

Nos referiremos finalmente, para su contrastación, a los materiales del poblado de S. Bartolomé en Almonte, en el que se han excavado conjuntos cerrados, y se ha advertido una secuencia horizontal desde comienzos del siglo VIII a comienzos del VI a.n.e.. Los resultados de las excavaciones son bien conocidos en la monografía publicada (Ruiz Mata y Fernández Jurado, 1986), y de ellos ofrecemos una breve síntesis y un análisis más detallado del fondo I.1, que corresponde a la época que analizamos en este trabajo.

Se han excavado casi una treintena de estructuras, que corresponden a habitaciones, zonas de almacenamiento, de trabajo y a otros usos, de las cuales 20 han proporcionado materiales que permitiesen su análisis y fijar la cronología. Se advierte una estratificación horizontal, desde cabañas que contenían exclusivamente materiales indígenas característicos de una fase prefenicia, o de los primeros momentos de la presencia fenicia, pero sin importaciones, a otras con materiales indígenas más recientes, que cuentan con escaso material fenicio, reducido principalmente a ánforas, urnas o algún que otro material exótico, datable en el siglo VII a.n.e., quizás en su primera mitad. Una de las cabañas -denominada I.1- proporcionó un conjunto de materiales de gran interés para analizar el proceso de cambio de la vajilla indígena por la torneada fenicia, las ánforas contenedoras de vino y aceite, la demanda de cerámica gris y la introducción de formas exóticas.

De este fondo computamos sólo los fragmentos que nos han proporcionado formas, desistiendo, por ejemplo, en la cerámica a torno de los fragmentos pintados o asas, que pueden pertenecer a las urnas u otras formas cerradas contabilizadas por sus bordes. Se trata, pues, de un análisis aproximativo, pero elocuente para el razonamiento que mantenemos en el trabajo.

- Se han distinguido claramente 133 formas, de las cuales 61 corresponden a material indígena y 72 a vasos fenicios.

- De los 61 fragmentos de material indígenas $-45.86 \%$ del total-, se sitúan tipológicamente en un momento prefenicio -4- o de comienzos de los contactos -11-, y todos ellos son de cazuelas y copas. Se trata de un material más antiguo que ha sobrevivido o aún lo fabricaba algún alfarero. Del resto, 146 se fabricaban generalmente en este momento, como demuestran los restos de otras cabañas del poblado, y aquí, como cabía esperar, se advierte un elenco más variado: 5 cazuelas, 5 copas, 9 cuencos, 15 urnas y 12 ollas, es decir, los elementos básicos de la cocina y almacenamiento. La mayoría de las ollas decoran sus hombros mediante impresiones digitadas o incisiones.

- 72 son las formas a torno $-54,14 \%$ del total-, de las que hay que precisar ciertos aspectos: A) las formas abiertas corresponden casi a la mitad de las cerámicas a torno -32 fragmentos-, y de ellas 28 , que 
suponen $38,89 \%$ de la cerámica a torno, corresponden a platos y cuencos grises ( 8 de bordes cóncavos, 18 cuencos de bordes engrosados y 2 de bordes apuntados), mientras que en engobe rojo -5.55 en SB y 4,08 en Vaina- , sólo se constata 1 plato, 1 cuenco de engobe rojo, 2 fuentes también de engobe rojo y 2 cuencos sin engobe. Es evidente que la cerámica gris fue el producto más demandado y son muy escasas las formas de engobe rojo; B) se han hallado 10 bocas de urnas, que son significativas en dos sentidos: primero porque comparten ya su función con las urnas de almacenaje a mano, y en segundo lugar ofrecen una tipología avanzada, de comienzos del siglo VI a.n.e., si se comparan con la evolución formal del CDB (Ruiz Mata 1986-b y 1987), en donde en esta época los cuellos son más abocinados, la misma tendencia que se advierte en el Cerro Macareno (un material que excavamos en 1974 y aún no se ha publicado); C) Las ánforas son muy numerosas -23 bocas pertenecientes a otras tantas ánforas, el $31,94 \%$ de la cerámica a torno-, contrastando con Vaina $(9,66 \%$ ) y El Trobal $(4,42 \%)-$, y ofrecen tipologías al menos de la segunda mitad del siglo VII/comienzos del VI a.n.e. Parece evidente que tal número de ánforas no suministraba sólo las necesidades de la cabaña I.1, sino que debieron estar allí almacenadas para su distribución; D) el resto del material se reparte del siguiente modo: una ampolla, un quemaperfumes, un trípode, un vaso globular y una jarra de dos asas.

\section{CONCLUSIONES}

La información barajada en este trabajo tiene como objetivo -además de aportar nuevos datos de establecimientos indígenas rurales protohistóricos- reflexionar, de modo síntetico y general, sobre dos temas que se han considerado importantes en el análisis de la fase orientalizante en Andalucía Occidental, el urbanismo y la cerámica a torno, valorados como indicadores del cambio cultural de las poblaciones del Bronce Final a las de época orientalizante o tartésica, si se sitúa el florecimiento de esta cultura entre los siglos VIII y VI a.n.e. Teniendo en cuenta los datos expuestos, mantenemos las conclusiones siguientes:

1. Los hábitats del Bronce Final, anteriores a la presencia fenicia, continúan, en cuanto a la disposición espacial y tecnología de las viviendas, los esquemas iniciados desde el Cobre, según se advierte en numerosos hallazgos repartidos por Andalucía Occidental: núcleos de estructuras establecidos en un territorio amplio, entre espacios libres, destinados a la producción agropecuaria y a zonas de trabajo; la vivienda se compone de varias estructuras separadas, con funciones definidas. Es preciso, en los planteamientos presentes y futuros de investigación, excavar espacios extensos que proporcionen más datos sobre la estructura y función de los espacios de estos hábitats.

2. Los estudios de territorio, que se realizan en la Baja Andalucía, denotan intensidad de poblamiento. Se conocen más de 500 asentamientos, de distinta índole, que configuran un panorama complejo en la organización socioeconómica de las poblaciones indígenas protohistóricas, distribuidas en territorios y con fronteras posiblemente bien definidas. Los análisis intensivos que aborden estos problemas deben contemplar una metodología y planteamiento adecuados que conduzcan al conocimiento de la estructura política de los mismos, para diferenciar los posibles centros, y núcleos del poder político, de otros asentamientos -villas o caseríoscon ellos relacionados.

3. Cuando se habla de Tartesos, como cultura aldeana, partiendo de la base de la supremacía de los modelos fenicios sobre los hábitats indígenas, deben tenerse en cuenta otros factores, y no sólo la morfología de las viviendas, como la extensión de los poblados, la intensidad de ocupación del territorio y su estructuración compleja. Sin tener esto en cuenta, no será fácil explicar la presencia fenicia en las costas meridionales -y en este trabajo nos referimos sólo al Bajo Guadalquivir- y los procesos de interacción y de orientalización, si por ello entendemos cambios en los sistemas socioeconómicos indígenas motivados por un concepto distinto de 
producción y comercio, pues el término "colonización" que implica la dicotomía de colonizador/colonizado, dominador/dominado, no se adecúa a la realidad que ofrecen los datos arqueológicos.

4. No conocemos demasiado sobre los hábitats indígenas ni sobre las ciudades fenicias -y en este caso nos referimos al prototipo que debió constituir Gadir, de la que sólo se conocen unos pocos restos de muros del siglo VII a.n.e-, o de los establecimientos comerciales o factorías. Sólo restos de viviendas, la mayoría de las veces de plantas incompletas, trozos de murallas, técnicas constructivas y poco más. Datos insuficientes para la reconstrucción de un modelo de ciudad o de factoría. Y es probable que el concepto de ciudad oriental no se repitiese fielmente en Occidente.

En nuestra opinión, la asunción de los aspectos formales técnicos tuvo lugar en los centros indígenas de mayor protagonismo en la relación comercial de fenicios e indígenas, es decir, en las sedes de las jefaturas locales, con quienes los fenicios establecían un intercambio directo. La intensificación de la producción, el surgimiento de jefaturas más consistentes y de la estratificación social más acusada condujo a la adopción del modelo de ciudad fenicia, por necesidades económicas y como expresión de la nueva sociedad surgiente.

5. Sin embargo, no debemos considerar estos cambios como un proceso generalizado. Durante el siglo VII y comienzos del VI a.n.e. muchos poblados indígenas, que posiblemente dependían o estaban inmersos en el sistema productivo de los grandes centros, no cambiaron sus estructuras de hábitats, pero aceptaron la nueva vajilla cerámica fenicia y estaban inmersos también en los sistemas de intercambios, a juzgar por las ánforas registradas, que contendrían seguramente vino y aceite, y otros productos perecederos que no han llegado hasta nosotros. La coexistencia de ciudades indígenas, según modelos fenicios, y los asentamientos que continuaron los tipos genuinos fue perfectamente compatible y muestra la realidad del período orientalizante o tartésico, cuya definición no estriba sólo en el nacimiento de la ciudad, sino en los cambios en los sistemas de producción, y en el control de los excedentes.

6. En cuanto a la cerámica, pese a que se van conociendo los tipos cerámicos fenicios e indígenas y su desarrollo morfológico general durante la protohistoria -aún hay que trabajar mucho en estos aspectos-, haciendo de ellos casi el único objetivo de análisis histórico-cultural del I milenio a. n.e., la realidad es que ni siquiera se ha alcanzado este propósito. No se han realizado aún estudios completos de la cerámica fenicia sobre todo la de época arcaica-, y en muchos casos hay serias dudas sobre cronologías y procedencias. Y esto vale en general para la cerámica fenicia en el Mediterráneo e incluso en sus lugares de origen orientales. En ellas está la razón para hablar de fenicios, de sus lugares de procedencia, de aculturación, interacción, intercambios, y la justificación de matizar y determinar el tiempo.

7. A través de una serie de ejemplos -los analizados en este estudio-, basados en conjuntos cerrados bien definidos, se puede percibir el proceso de integración y adopción, por parte de la población indígena, de la vajilla fenicia, que nos ha conducido a las siguientes consideraciones:

7.1. En los fondos de cabañas del siglo VIII a.n.e. -más bien desde mediados de este siglo-, el porcentaje predominante es el material indígena a mano, como cabía esperar, en donde en ocasiones se advierten unos pocos vasos de importación, que denotan los productos no perecederos que los fenicios intercambiaban por otros que desconocemos. A veces son ánforas, que contendrían vino y aceite, y en otros casos son exóticos y de prestigio, no funcionales, como ampollas para pefumes o aceites perfumados, oinocóes, copas, páteras o algún tipo especial, como el frutero recogido en una cabaña en Campillo (El Puerto de Santa María).

7.2. En los fondos analizados, que se datan a partir de la segunda mitad del siglo VII a.n.e., los tipos y porcentajes cambian sustancialmente, advirtiéndose el predominio de la producción a torno fenicia, con fines industriales y comerciales, en detrimento de la cerámica tradicional, ahora de peor calidad y que ha perdido en perfección artesana y decorativa. El repertorio, en conjunto, es mucho más amplio y funcional; es decir, los alfareros producen con fines industriales, más cantidad a cambio de la calidad, escaseando las decoraciones, 
y cuando las hay son torpes y desmañadas. El esfuerzo del trabajo se emplea en la producción de otros productos, y resulta más rentable la compra de cerámicas a torno.

7.3. El elenco de un poblado fenicio, como el del $\mathrm{CDB}$, comparado con el de otro indígena ofrece distinciones. Se advierte una clara diferencia en las formas abiertas -platos y páteras de engobe rojo-, formas usuales en medios fenicios y escasas en los indígenas, que demandaron platos y cuencos grises, más cercanos a sus tipos genuinos. En los poblados fenicios su uso es menos frecuente. Los vasos de almacenamiento, del tipo "à chardon" se fueron sustituyendo por los "pithoi". Igualmente son escasas las lucernas en los poblados indígenas, como medio de iluminación, que debieron seguir empleando otros recursos que desconocemos. Se podrían señalar muchas diferencias, que no vienen al caso.

7.4. Por último, insistir en la necesidad de excavación y análisis de conjuntos cerrados, que puedan proporcionar porcentajes de los tipos cerámicos, para adentrarnos, desde este punto de vista, en los procesos de interacción de fenicios e indígenas y en el tiempo que denominamos "orientalizante". Las estratigrafías han servido durante un tiempo, pero no dan respuesta a muchas de las preguntas sobre los procesos.

\section{BIBLIOGRAFÍA}

AMORES, F. y RODRÍGUEZ HIDALGO, J.M. (1987): "Cogotas en Carmona y panorama general sobre este fenómeno en Andalucía Occidental”, Mainake VI-VII: 73-90.

ARANEGUI, C. (1975): “La cerámica gris monócrama. Puntualizaciones sobre su estudio". P.L.A.V. n⿳ 11: 333 y ss. Valencia.

AUBET M".E. (1974): “Excavaciones en Las Chorreras (Mezquitilla, Malaga)”, Pyrenae 10: 79-108.

- (1989): "La Mesa de Setefilla: la secuencia estratigráfica del Corte 1", Tartessos, Arqueología protohistórica del Bajo Guadalquivir. Sabadell: 297-338.

AUBET, M". E.; MAASS-LINDEMANN, G. y SCHUBART, H. (1979): "Chorreras. Un establecimiento fenicio al Este de la desembocadura del Algarrobo", Noticiario Arqueológico Hispánico 6: 219-258.

AUBET M".E. y otros. (1983): La Mesa de Setefilla. Lora del Río (Sevilla). Campaña de 1979. E.A.E. 122. Madrid.

BANDERA ROMERO, Mㄹ.L. de la y otros. (1993): "Montemolín. Evolución del asentamiento durante el Bronce Final y el período Orientalizante (Campaña de 1980 y 1981)". Anales de Arqueología Cordobesa 4: $15-47$.

BELÉN DEAMOS, M. (1976): "Estudio y tipología de la cerámica gris en la provincia de Huelva". Revista de Archivos Bibliotecas y Museos LXXIX, ํำ 2: 354-387. Madrid.

BELÉN DEAMOS, M.; FERNÁNDEZ-MIRANDA, M. y GARRIDO ROIG, J. P. (1977): “Los orígenes de Huelva. Excavaciones en los cabezos de San Pedro y la Esperanza". Huelva Arqueológica III.

BELÉN, M. y ESCACENA, J.L. (1992): "Las comunidades prerromanas de Andalucía Occidental". Paleoetnología de la Península Ibérica. Complutum 2-3: 65-87.

BENDALA GALAN, M. (1989): "La génesis de la estructura urbana en la España antigua". Cuadernos de Prehistoria y Arqueología de la UAM 16: 127-147.

BIKAI, P.M. (1978): The Pottery of Tyre. Warminster.

BLANCO, A.; LUZÓN, J. M. y RUIZ MATA, D. (1970): Excavaciones arqueológicas en el Cerro Salomón (Riotinto, Huelva). Sevilla.

- (1969): "Panorama tartésico en Andalucía Occidental". V Symposium Internacional de Prehistoria Peninsular (Jerez, 1968) Barcelona: 119-162.

BLANCO, A. y ROTHENBERG, B. (1981): "Excavaciones de Tejada La Vieja”. Exploración Arqueometalúrgica de Huelva. Labor S.A.: 229-282. 
BLÁZQUEZ, J.M. y otros. (1979): Excavaciones en el Cabezo de San Pedro. (Huelva). Campaña de 1977. E.A.E. 102. Madrid.

BUERO MARTÍNEZ, M.S. (1987): "El Bronce Final y las cerámicas “Tipo Carambolo"”. Revista de Arqueología, 70: 36-47.

- (1984): "Los motivos naturalistas en la cerámica a mano pintada del Bronce Final del Suroeste Peninsular". Habis 15: 345-364.

CABRERA BONET, P. (1981): "La cerámica pintada de Huelva”. Huelva Arqueológica V: 317-335.

CAMPOS, J.M. (1986): Excavaciones arqueológicas en la ciudad de Sevilla. El origen Prerromano y la Hispalis Romana. Sevilla.

CAMPOS, J.M.; VERA, M. y MORENO, M.T. (1988): Protohistoria en la ciudad de Sevilla. El corte estratigráfico de San Isidoro, 85-6. Monografías de Arqueología Andaluza 1. Sevilla.

CAMPOS, J.M. y otros. (1993): "Dinámica de asentamientos y evolución de sistemas naturales. La secuencia holocena del litoral y prelitoral entre el Guadiana y el Guadalquivir. Ocupación y territorio en la Tierra Llana de Huelva". Investigaciones Arqueológicas en Andalucía 1985-1992. Proyectos. Huelva: 779-798.

CARO, A.; ACOSTA, P. y ESCACENA, J.L. (1987): "Informe sobre la prospección arqueológica con sondeo estratigráfico en el solar de la calle Alcazaba. (Lebrija, Sevilla)". Anuario Arqueológico de Andalucía 1986, Vol. II: 168-174.

CARRIAZO, J. de M. (1961-62): "El dolmen de Ontiveros (Valencina de la Concepción, Sevilla). Homenaje al profesor C. Mergelina, Murcia: 1-21.

- (1969): "El cerro del Carambolo". V Symposium Internacional de Prehistoria Peninsular (Jerez, 1968). Barcelona: 311-340.

- (1973): Tartessos y El Carambolo. Madrid.

- (1978): El Carambolo.Sevilla.

CARRIAZO, J. de M. y RADDATZ, K. (1960): "Primicias de un corte estratigráfico en Carmona". Archivo Hispalense: 103-104; 333-369.

COLLANTES DE TERÁN, F. (1969): "El dolmen de Matarrubilla (Sevilla)”. V Symposium Internacional de Prehistoria Peninsular (Jerez, 1968) Barcelona: 47-61.

DOMÍNGUEZ DE LA CONCHA, M.C.; CABRERA BONET, P. y FERNÁNDEZ JURADO, J. (1988): “Cerro de la Cabeza (Santiponce, Sevilla)". Noticiario Arqueológico Hispánico nº 30: 131-186. Madrid.

CHAVES TRISTÁN, F. y otros. (1993): “Montemolín 1980-1992". Investigaciones arqueológicas en Andalucía 1985-1992. Proyectos. Huelva: 501-514.

ESTEVE GUERRERO, M. (1945): Excavaciones de Asta Regia (Mesas de Asta, Jerez). Campaña 1942-43. Acta Arqueológica Hispánica III. Madrid.

- (1950): Excavaciones de Asta Regia (Mesas de Asta, Jerez). Campaña 1945-46. Informes y Memorias de la Comisión de Excavaciones Arqueológicas 22. Madrid.

- (1962): Excavaciones de Asta Regia (Mesas de Asta, Jerez). Campaña 1949-1950 y 1955-56. Centro de Estudios Históricos Jerezanos 19. Jerez.

- (1969): "Asta Regia: Una ciudad tartésica". V Symposium Internacional de Prehistoria Peninsular. (Jerez, 1968). Barcelona: 111-118.

FERNÁNDEZ GÓMEZ, F.; CHASCO VILA, A. y OLIVA ALONSO, D. (1979): "Excavaciones en el "Cerro Macareno" La Rinconada, Sevilla (cortes E,F,G, Campaña 1974)". Noticiario Arqueológico Hispánico 7 : 11-93.

FERNÁNDEZ GÓMEZ, F. y OLIVA ALONSO, D. (1985): "Excavaciones en el yacimiento calcolítico de Valencina de la Concepción (Sevilla). El corte C -La Perrera-". Noticiario Arqueológico Hispánico 25: 9131. 
- (1986): "Valencina de la Concepción (Sevilla). Excavaciones de urgencia”. Revista de Arqueología 58: 19-33. FERNÁNDEZ GÓMEZ, F. y RUIZ MATA, D. (1978): "El "tholos" del Cerro de la Cabeza, en Valencina de la Concepción (Sevilla)". Trabajos de Prehistoria 35: 193-224.

FERNÁNDEZ JURADO, J. (1987): Tejada La Vieja: Una ciudad protohistórica. Huelva Arqueológica IX. - (1988-89): Tartessos y Huelva. Huelva Arqueológica X-XI.

FERNÁNDEZ JURADO, J.; GARCÍA SANZ, C. y RUFETE TOMICO, P. (1990): "Prospección con sondeo en Peñalosa (Escacena, Huelva)”. Anuario Arqueológico de Andalucía 1990, Vol I: 185-190.

FLORIDO NAVARRO, M.C. (1985): "Las ánforas del poblado orientalizante e ibero-púnico del Carambolo (Sevilla)". Habis 16: 487-516.

GARCÍA RINCÓN, J. M. (1987): “Aproximación al estudio espacial del área de Teajada la Vieja”, Huelva Arqueológica IX: 191-219.

GARCÍA SANZ, C. (1988-89): "El urbanismo protohistórico de Huelva". Huelva Arqueológica X-XI, Vol. 3:143-175.

GONZÁLEZ RODRÍGUEZ, R. (1987): "El yacimiento de "El Trobal" (Jerez de la Frontera). Nuevas aportaciones a la cultura de los silos de la Baja Andalucía". Anuario Arqueológico de Andalucía 1986, Vol. III: $82-88$.

GONZÁLEZ RODRÍGUEZ, R.; BARRIONUEVO, F. y AGUILAR, L. (e.p.): "Mesas de Asta. Un centro indígena tartésico en los esteros del Guadalquivir". Actas del Congreso "Tartessos, 25 años después" (Jerez, 1993).

GONZÁLEZ RODRÍGUEZ, R. y otros. (1993): "Paleogeografía humana del extremo noroccidental de Cádiz. Los procesos culturales desde el Neolítico a época Medieval". Investigaciones Arqueológicas en Andalucía 1985-1992. Proyectos. Huelva: 799-806.

GONZÁLEZ WAGNER, C. (1992): “Recensión: Tartessos. Arqueología Protohistórica del Bajo Guadalquivir". Spal 1: 357-365.

HURTADO, V. (1993): “Análisis y definición de los procesos culturales del II milenio a.C. en el suroeste peninsular”. Investigaciones Arqueológicas en Andalucía 1985-1992. Proyectos. Huelva: 461-470.

HURTADO, V. y GARCÍA SANJUAN, L. (1994): “Áreas funcionales en el poblado de la Edad del Bronce de El Trastejón (Zufre, Huelva)". Arqueología en el entorno del Bajo Guadiana. Huelva: 239-271.

LADRÓN DE GUEVARA, I. (1994): Aportación al estudio de la cerámica con impresiones digitales en Andalucía. Servicio de Publicaciones. Universidad de Cádiz.

LEISNER, G. y V. (1943): Die Megalithgräber der Iberischen Halbinsel I. Des Süden. Berlín.

LEISNER, G. y V. y CERDÁN, C. (1952): Los sepulcros megalíticos de Huelva. Informes y Memorias de la Comisaría General de Excavaciones Arqueológicas nº 26. Madrid.

LÓPEZ ROA, C. (1977): "Las cerámicas con decoración bruñida en el suroeste peninsular". Trabajos de Prehistoria 34:

— (1978): "Las cerámicas alisadas con decoración bruñida". Huelva Arqueológica IV: 145-180.

MAASS LINDEMANN, G. (1986): "Vasos fenicios de los siglos VIII-VI en España. Su procedencia y posición dentro del mundo fenicio Occidental". Los Fenicios en la Península Ibérica I: 227-240.

MANCEBO, J. (1991-92): "La cerámica de barniz o engobe rojo de Montemolín, Sevilla". Zephyrus XLIVXLV: 269-299.

MAYET, F. y TAVARES DA SILVA, C. (1992): “Abul: um estabelecimiento orientalizante do século VII a.C. ho baixo vale do Sado". Setúbal Arqueológica IX-X: 315-333.

- (1993): "A presença fenicia no Baixo Sado". Estudios Orientais IV. Lisboa:127-142.

MARTÍN DE LA CRUZ, J.C. (1976): "El corte F del Cerro Macareno. La Rinconada (Sevilla)". Cuadernos de Prehistoria y Arqueología de la UAM 3: 9-32. 
MUÑOZ VICENTE, A. (1987): “Las ánforas prerromanas de Cádiz (Informe preliminar)”. Anuario Arqueológico de Andalucía 1985, Vol. II: 471-478.

NEGUERUELA, I. (1979-80): "Sobre la cerámica de engobe rojo en España". Habis 10-11: 335-359.

NIEMEYER, H. G.(1979): "Toscanos. Campañas de 1973 y 1976 (con un apéndice sobre los resultados de la campaña de 1978)", Noticiario Arqueológico Hispánico 6: 218-258.

- (1982): “El yacimiento fenicio de Toscanos: balance de la investigación. 1964-1979", Huelva Arqueológica VI: 101-130.

- (1986): “El yacimiento fenicio de Toscanos: urbanística y función”, Los Fenicicos en la Península Ibérica, Ausa, Vol.I: 109-126.

NOCETE, F. y Otros. (1993): "Proyecto Odiel. Un año después (1991-1992). 3000-1000 a.n.e. Formaciones sociales en transición: Un modelo de análisis histórico para la contrastación del proceso de jerarquización social". Investigaciones Arqueológicas en Andalucía 1985-1992. Proyectos. Huelva: 383-400.

OBERMAIER, H. (1919): "El dolmen de Matarrubilla (Sevilla". Memorias de la Comisión de Investigaciones Paleontológicas y Prehistóricas $\mathrm{n}^{\mathrm{O}}$ 26. Madrid.

PELLICER, M. (1979): "Tipología y cronología de las ánforas prerromanas del Guadalquivir según el Cerro Macareno (Sevilla)". Habis 9 (1978): 365-400.

- (1982): "Las cerámicas del mundo fenicio en el Bajo Guadalquivir: evolución y cronología según el Cerro Macareno (Sevilla)". Madrider Beitrage 8: 371-406.

PELLICER, M. y AMORES, F. (1985): "Protohistoria de Carmona. Los cortes estratigráficos CA 80/A y CA 80/B”. Noticiario Arqueológico Hispánico 22: 55-189.

PELLICER, M.; ESCACENA, J.L. y BENDALA, M. (1983): El Cerro Macareno. E.A.E., 124. Madrid.

PERDIGONES, L. y Otros. (1987): "Excavaciones de urgencia en la Base Naval de Rota (El Puerto de Santa María, Cádiz)". Anuario Arqueológico de Andalucía 1985, Vol. III: 29-33.

PLÁCIDO SUÁREZ, D.; ALVAR EZQUERRA, J. y GONZÁLEZ WAGNER, C. (1991): La formación de los Estados en el Mediterráneo Occidental. Síntesis, Madrid.

RAMOS MUÑOZ, J. (1991): "El Estanquillo. Análisis microespacial de un asentamiento de la Edad del Bronce". Revista de Arqueología no 122: 14-23.

- (1991b): "Las industrias líticas del Bronce Final en Jerez. Renovación metodológica y perspectivas económicas de estudio". Páginas. Revista de Humanidades, Jerez: 238-262.

RAMOS MUÑOZ, J. y otros. (1993): "La ocupación prehistórica de la campiña, litoral y banda atlántica de Cádiz”. Investigaciones Arqueológicas en Andalucía 1985-1992. Proyectos. Huelva: 353-364.

ROSS, A.M. (1982): "Acerca de la antigua cerámica gris a torno en la Península Ibérica". Ampurias nº 44: 43 70. Barcelona.

RUIZ FERNÁNDEZ, J.A. (1987): "Informe excavaciones de urgencia. Pago de Cantarranas-La Viña. El Puerto de Santa María". Anuario Arqueológico de Andalucía 1986, Vol. III: 95-100.

RUIZ FERNÁNDEZ, J.A. y RUIZ GIL, J.A. (1989): "Calcolítico en El Puerto de Santa María". Revista de Arqueología 94: 7-13.

RUIZ GIL, J.A. y RUÍZ FERNÁNDEZ, J.A. (1987): "Excavaciones de urgencia en El Puerto de Santa María (Cádiz)". Revista de Arqueología no 74: 5-12.

RUIZ GIL, J.A. y otros. (1990): "El yacimiento protohistórico de las Beatillas (El Puerto de Santa María)". Revista de Historia de El Puerto $\mathrm{n}^{\mathrm{0}}$ 4: 11-38.

RUIZ MATA, D. (1975): "Cerámicas del Bronce del poblado de Valencina de la Concepción (Sevilla): los platos". Cuadernos de Prehistoria y Arqueología de la UAM 2: 123-151.

- (1981): "Excavaciones en el Cabezo de San Pedro (Huelva). Campaña de 1978". Huelva Arqueológica V: 149-316. 
- (1983): "El yacimiento de Valencina de la Concepción (Sevilla) en el marco cultural del Bajo Guadalquivir". Actas del I Congreso de Historia de Andalucía, Tomo I: 183-208.

- (1984-85): "Puntualizaciones sobre la cerámica pintada tartésica del Bronce Final -estilo Carambolo o Guadalquivir I-”. Cuadernos de Prehistoria y Arqueología de la UAM. 11-12. Vol. I: 225-243.

- (1986): "Aportación al análisis de los inicios de la presencia fenicia en Andalucía Sudoccidental, según las excavaciones del Cabezo de San Pedro (Huelva), San Bartolomé (Almonte, Huelva), Castillo de Doña Blanca (El Puerto de Santa María, Cádiz) y El Carambolo (Camas, Sevilla)". Homenaje a Luis Siret (Cuevas de Almanzora, 1984). Sevilla: 537-556.

- (1986b): "Las cerámicas fenicias del Castillo de Doña Blanca (El Puerto de Santa María, Cádiz)". Los Fenicios en la Península Ibérica, Sabadell, 1986, Vol. I: 241-267.

- (1987): "La formación de la cultura turdetana en la Bahía de Cádiz a través del Castillo de Doña Blanca". Actas de las I Jornadas sobre mundo Ibérico (Jaén 1985): 299-314

- (1988): “El Castillo de Doña Blanca, yacimiento clave de la protohistoria peninsular". Revista de Arqueología 85: 34-48.

- (1992): "Sobre la época arcaica fenicia (siglos VIII-VI a.C.) del Castillo de Doña Blanca (El Puerto de Santa María, Cádiz)". Revista de Historia de El Puerto no 8: 11-44.

- (1993): "Fenicios en la Bahía Gaditana. El Castillo de Doña Blanca (El Puerto de Santa María, Cádiz)". Metalurgia en la Península Ibérica durante el primer milenio a.C. Estado actual de la investigación. Murcia: $167-188$.

- (1993b): "Los fenicios de época arcaica -siglos VIII/VII a. C.- en la Bahía de Cádiz. Estado de la cueśtión", Estudos Orientais IV. Lisboa: 23-69.

- (1994): "El Bronce en el Bajo Guadalquivir". Edad del Bronce: Actas del curso de verano de la Universidad de Vigo (Xinzo de Limia 1993): 235-276.

- (1994b): "La secuencia prehistórica reciente de la zona occidental gaditana, según las recientes investigaciones". Arqueología en el entorno del Bajo Guadiana. Huelva: 279-328.

- (e.p.): "Las cerámicas del Bronce Final. Un soporte tipológico para definir el tiempo y el espacio tartésico". Actas del Congreso "Tartessos, 25 años después". (Jerez, 1993).

RUIZ MATA, D. y FERNÁNDEZ JURADO, J. (1986): El yacimiento metalúrgico de época tartésica de San Bartolomé de Almonte (Huelva). Huelva Arqueológica VIII.

RUFETE TOMICO, P. (1988-89): "Las cerámicas de engobe rojo en Huelva". Huelva Arqueológica X-XI, Vol. 3: 9-37.

- (1989): "Las cerámicas con barniz rojo de Huelva". Tartessos. Arqueología Protohistórica en el Bajo Guadalquivir. Sabadell: 375-394.

SCHUBART, H. (1979): "Morro de Mezquitilla. Informe preliminar sobre las excacavaciones de 1976", Noticiario Arqueológico Hispánico 6: 175-218.

— (1984): "Morro de Mezquitilla. Informe preliminar sobre la campaña de excavaciones de 1981", Noticiario Arqueológico Hispánico 19: 85-102.

- (1985): "Morro de Mezquitilla. Informe preliminar sobre la campaña de excavaciones de 1982", Noticiario Arqueológico Hispánico 23: 141-174.

- (1986): "El asentamiento fenicio del S. VIII a. C. en el Morro de Mezquitilla (Algarrobo, Málaga)". Los Fenicios en la Península Ibérica I: 59-83.

SCHUBART, H. y MAASS-LINDEMANN G. (1984): "Toscanos. El asentamiento fenicio occidental en la desembocadura del río Vélez. Excavaciones de 1971”. Noticiario Arqueológico Hispánico 18: 39-210. 


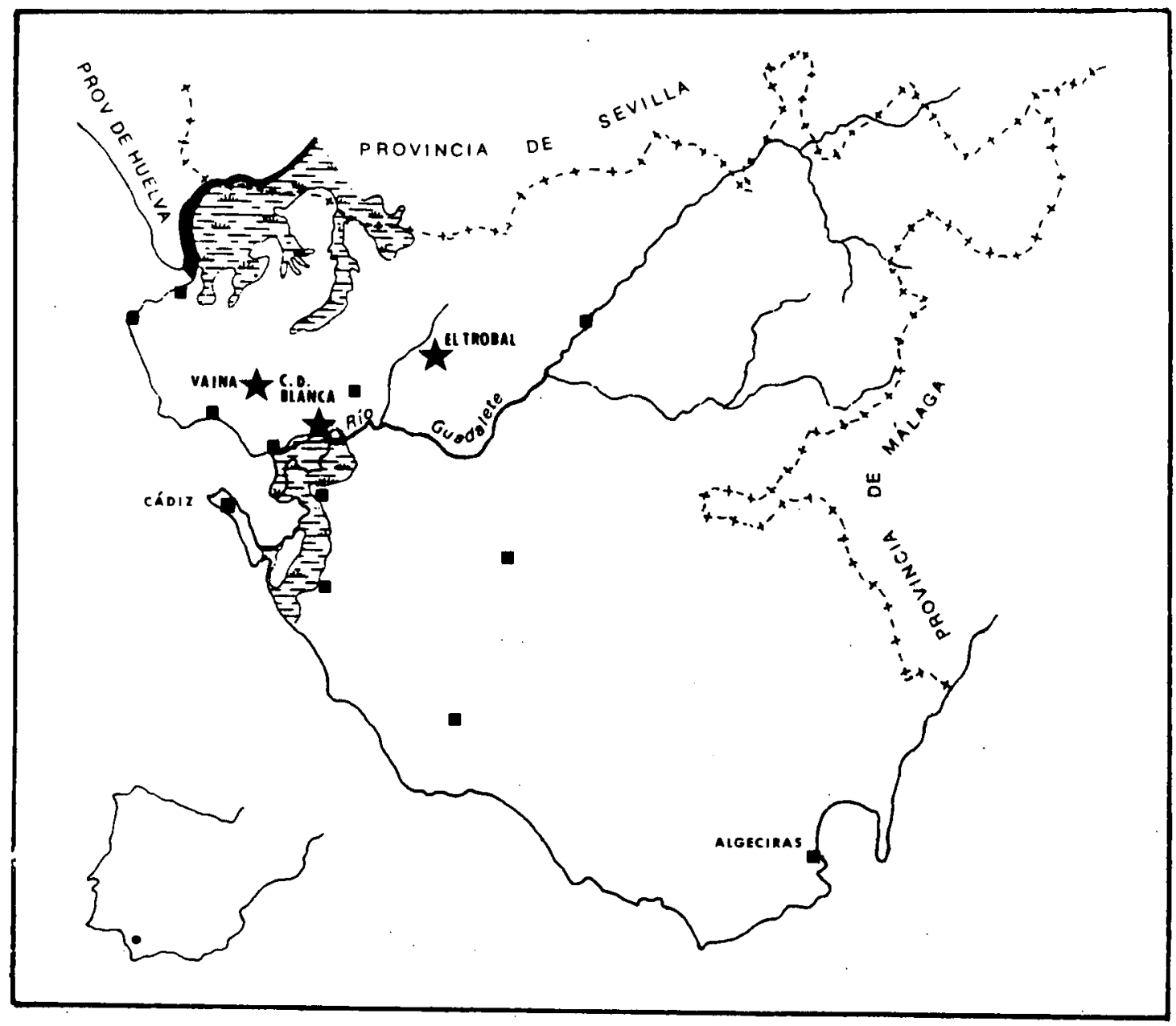

Fig. 1: Situación de los yacimientos de El Trobal, Castillo de Doña Blanca y Vaina. 

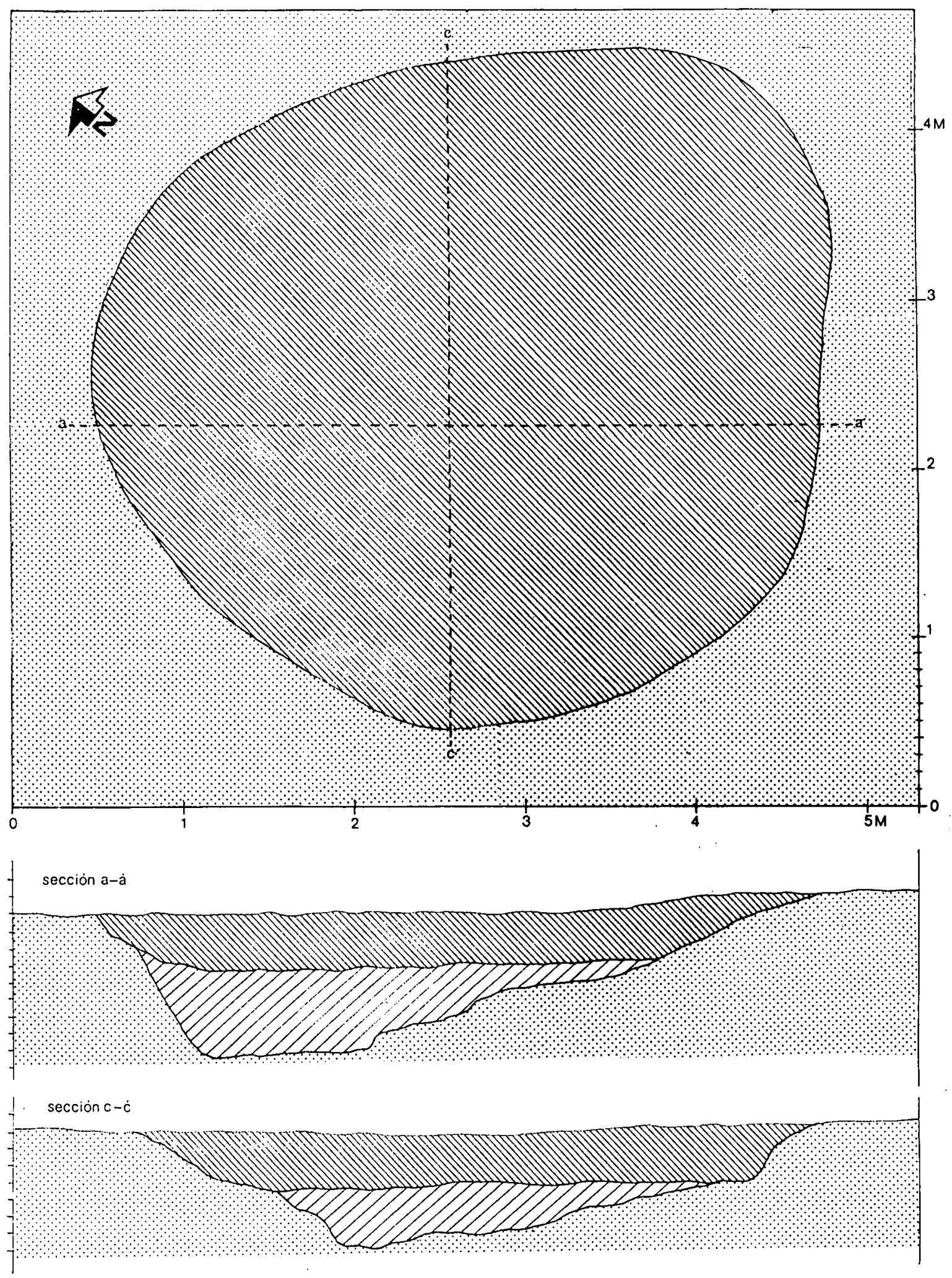

Fig. 2: Fondo de cabaña de El Trobal. Planta y secciones. 


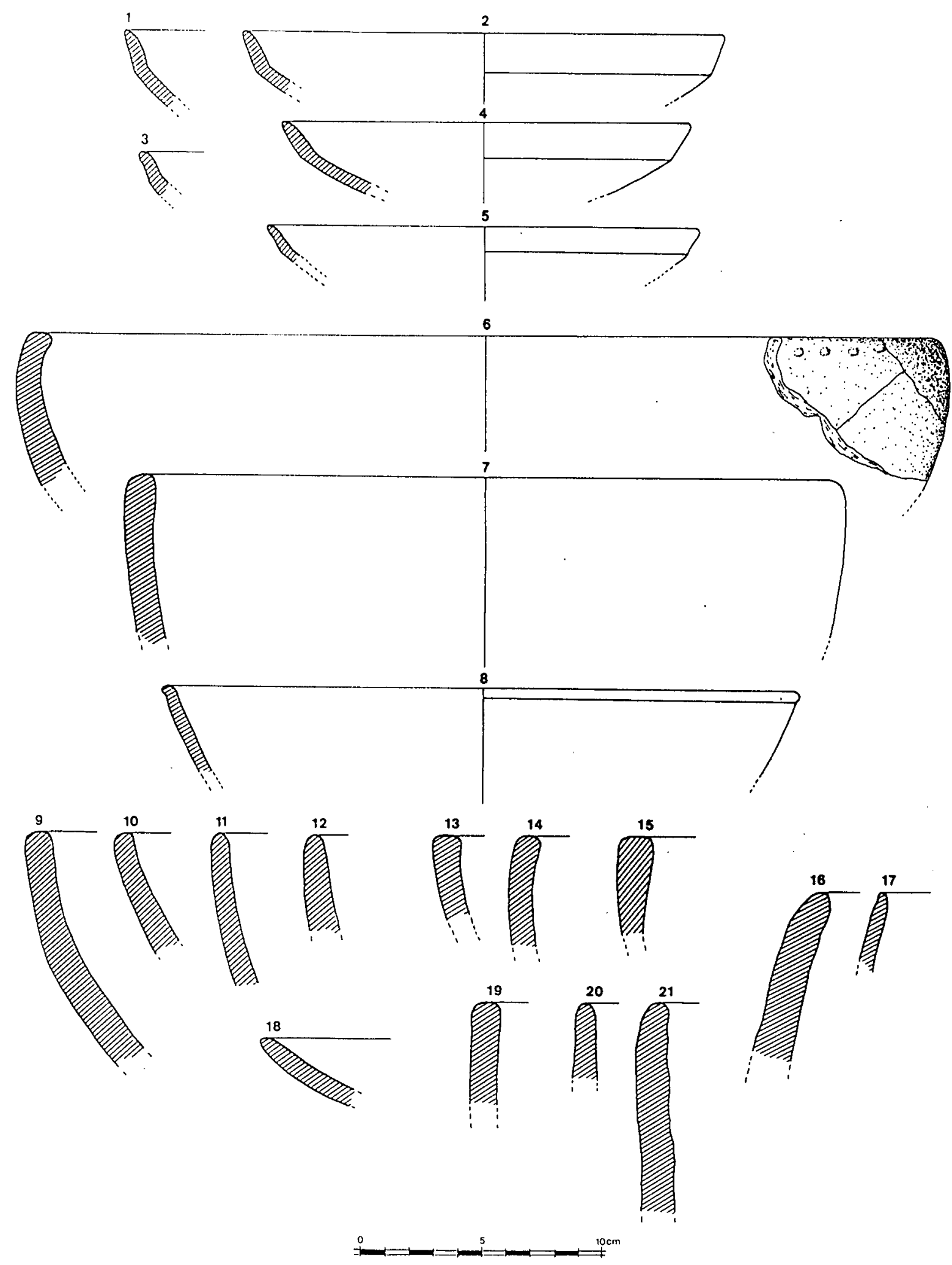

Fig. 3: El Trobal. Cerámica a mano. Cazuelas (1-5) y cuencos (6-21). 

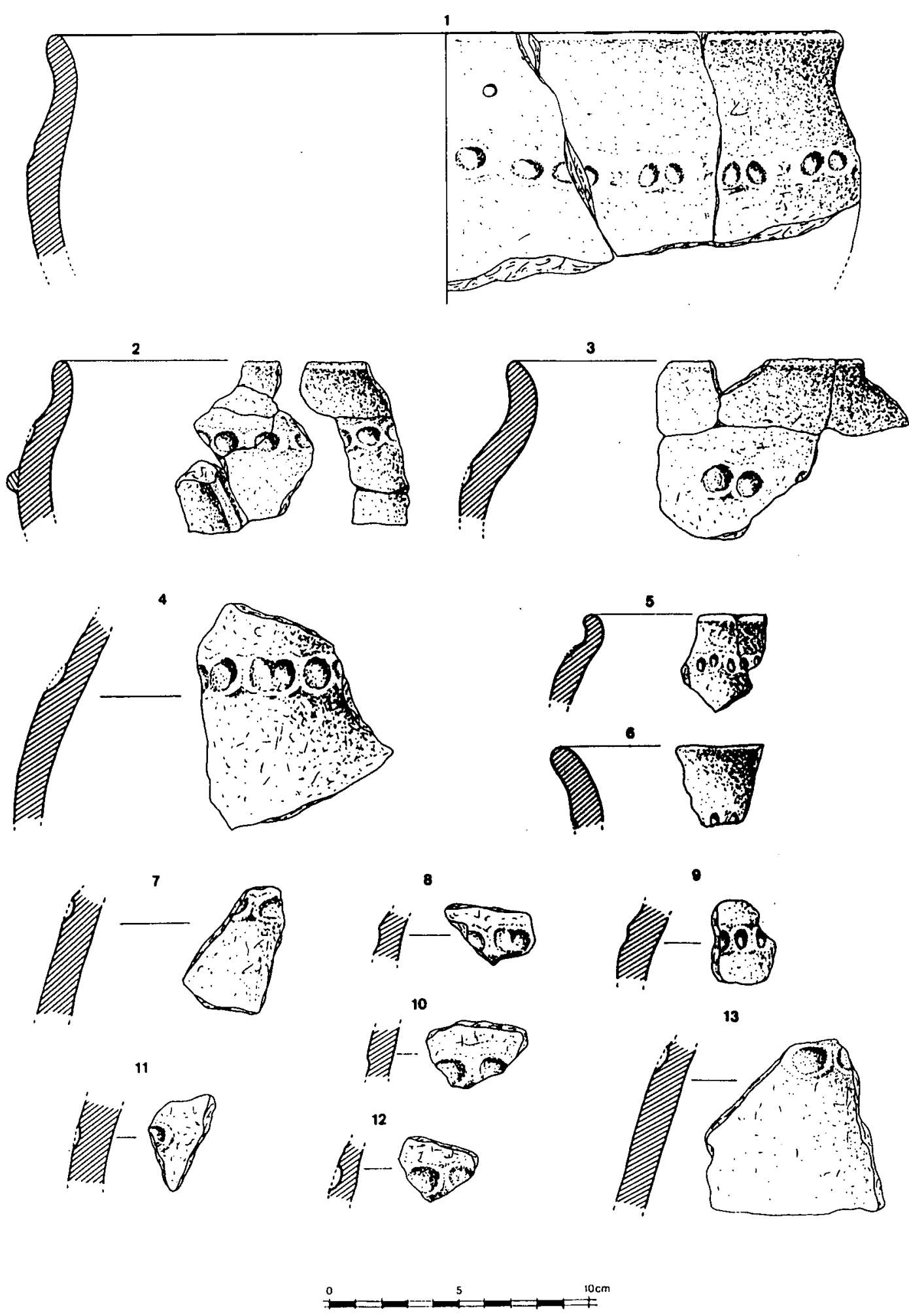

Fig. 4: El Trobal. Cerámica a mano. Ollas de cocina con decoración de digitaciones. 

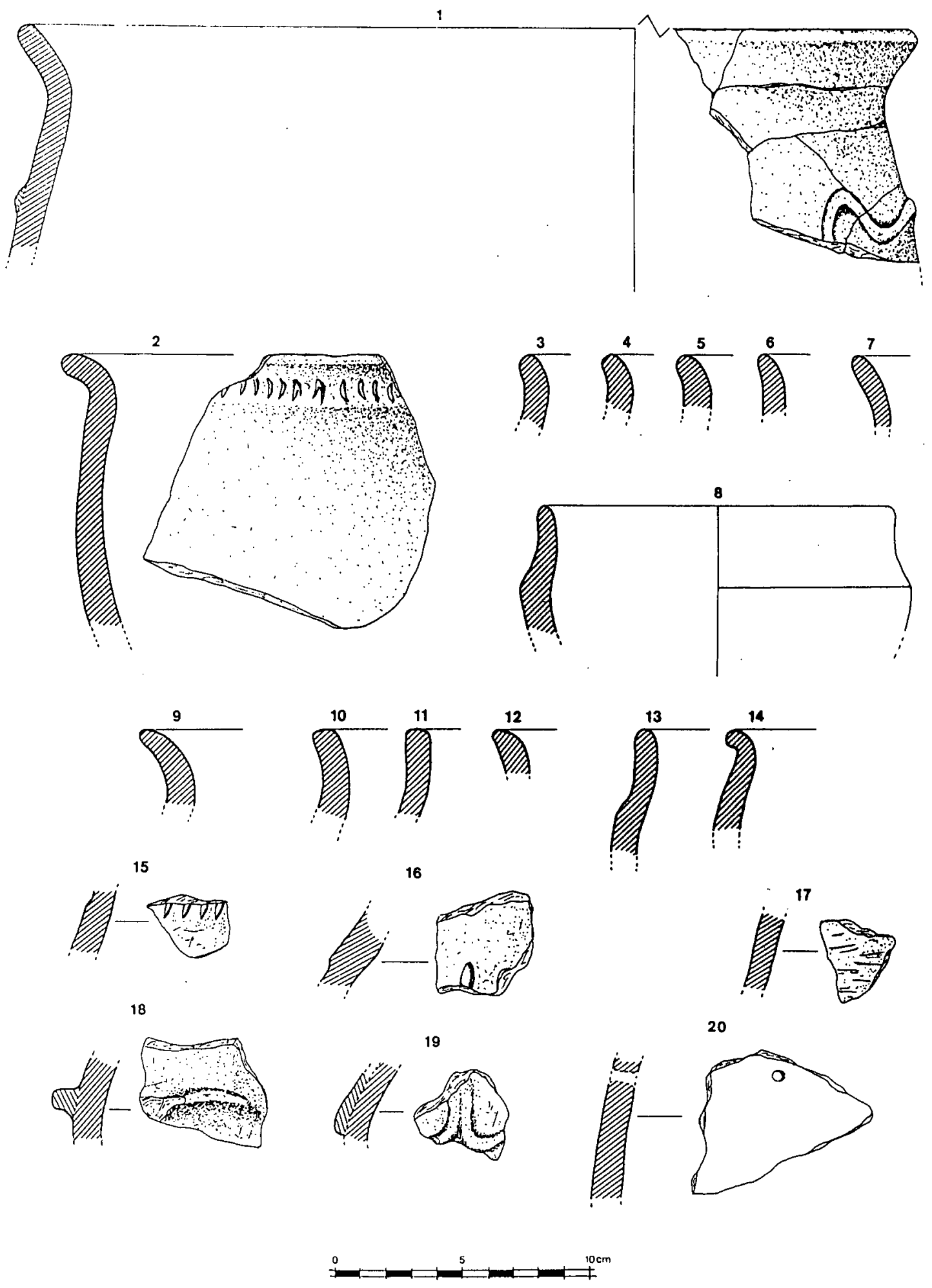

Fig. 5: El Trobal. Cerámica a mano. Ollas de cocina. 

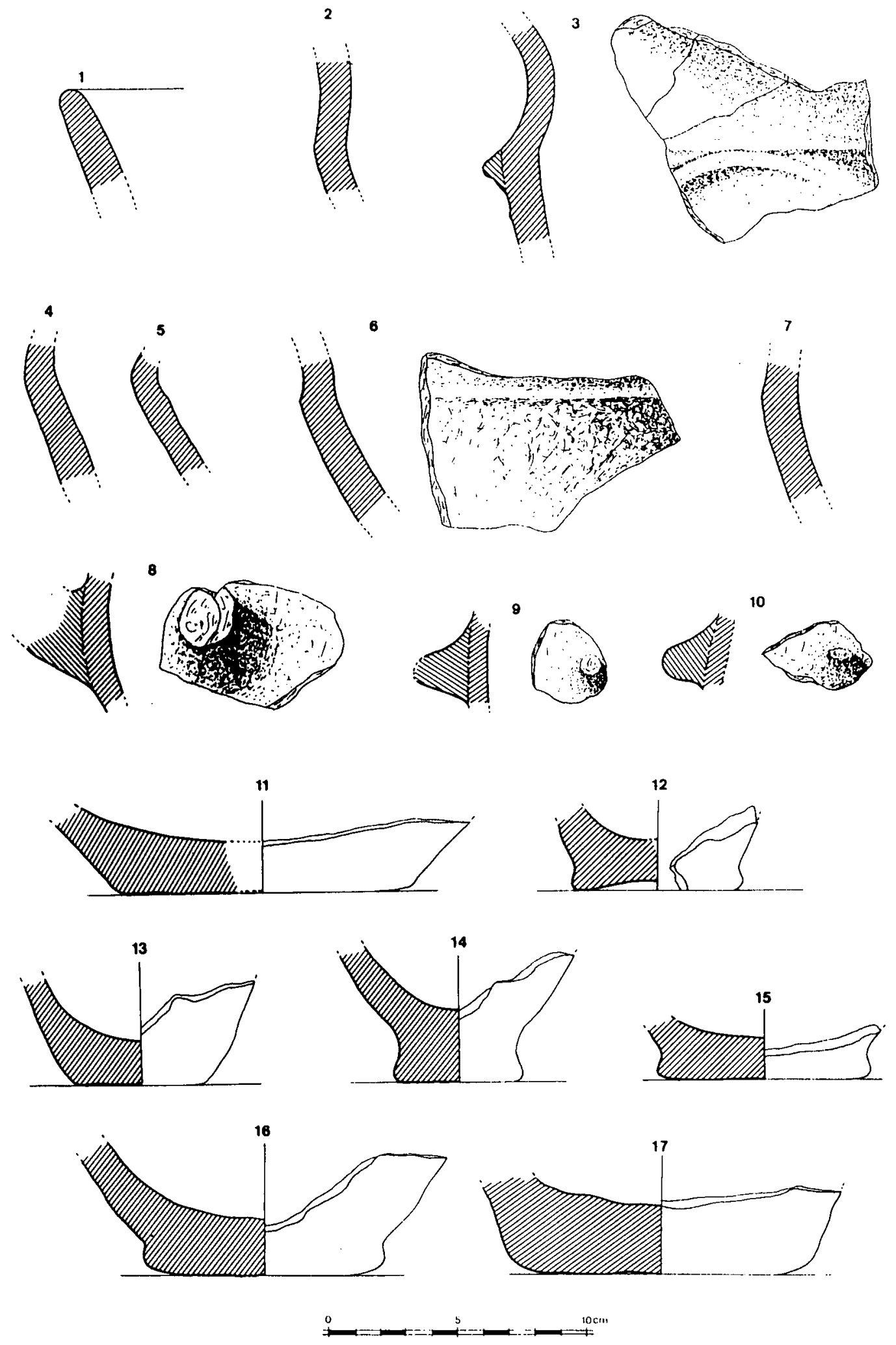

Fig. 6: El Trobal. Cerámica a mano. Vasos (1-7), asas (8-10) y fondos (11-17). 

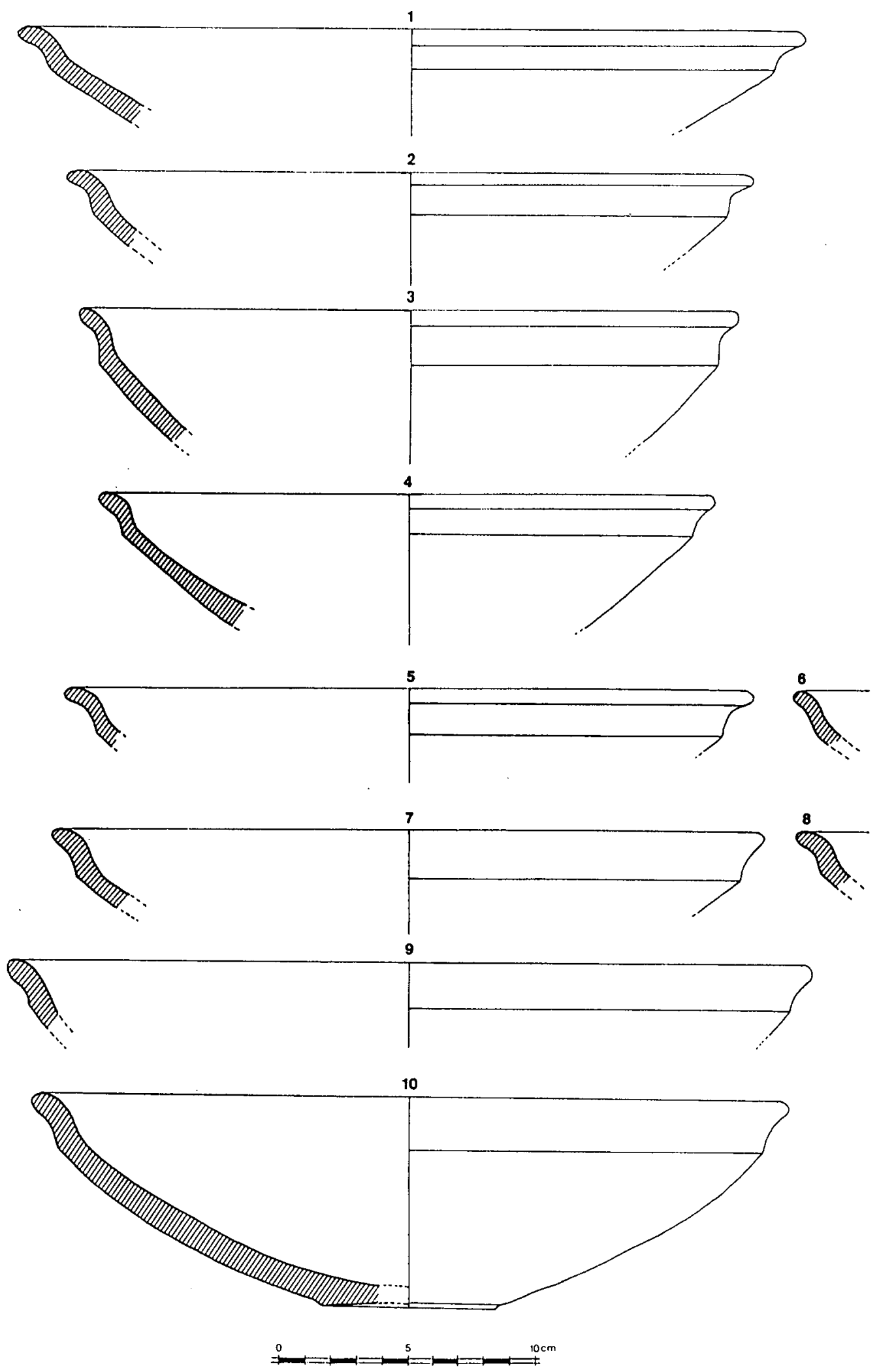

Fig. 7: El Trobal. Cerámica gris. Platos. 

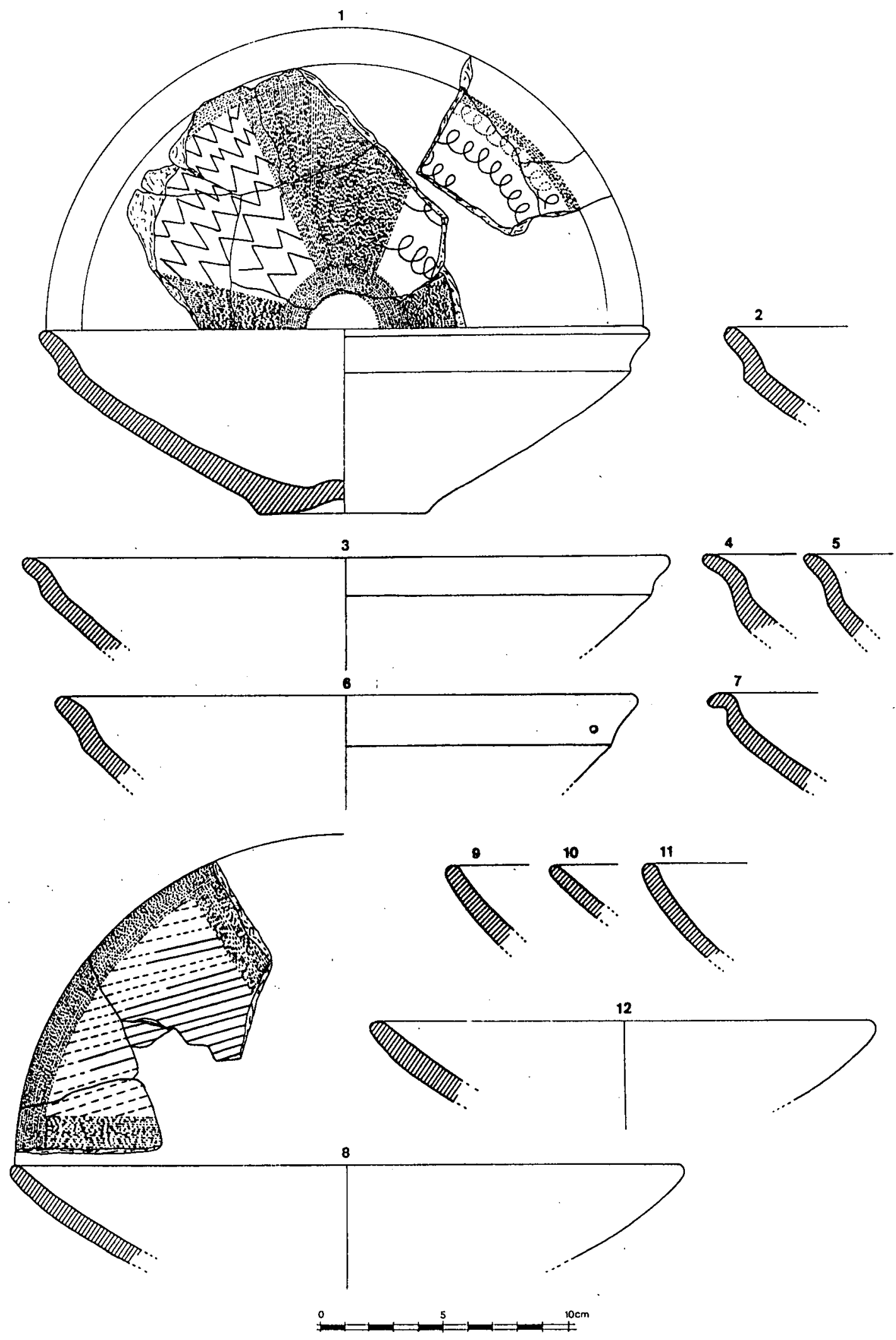

Fig. 8: El Trobal. Cerámica gris. Páteras (1-4) y fondos (6-9). 

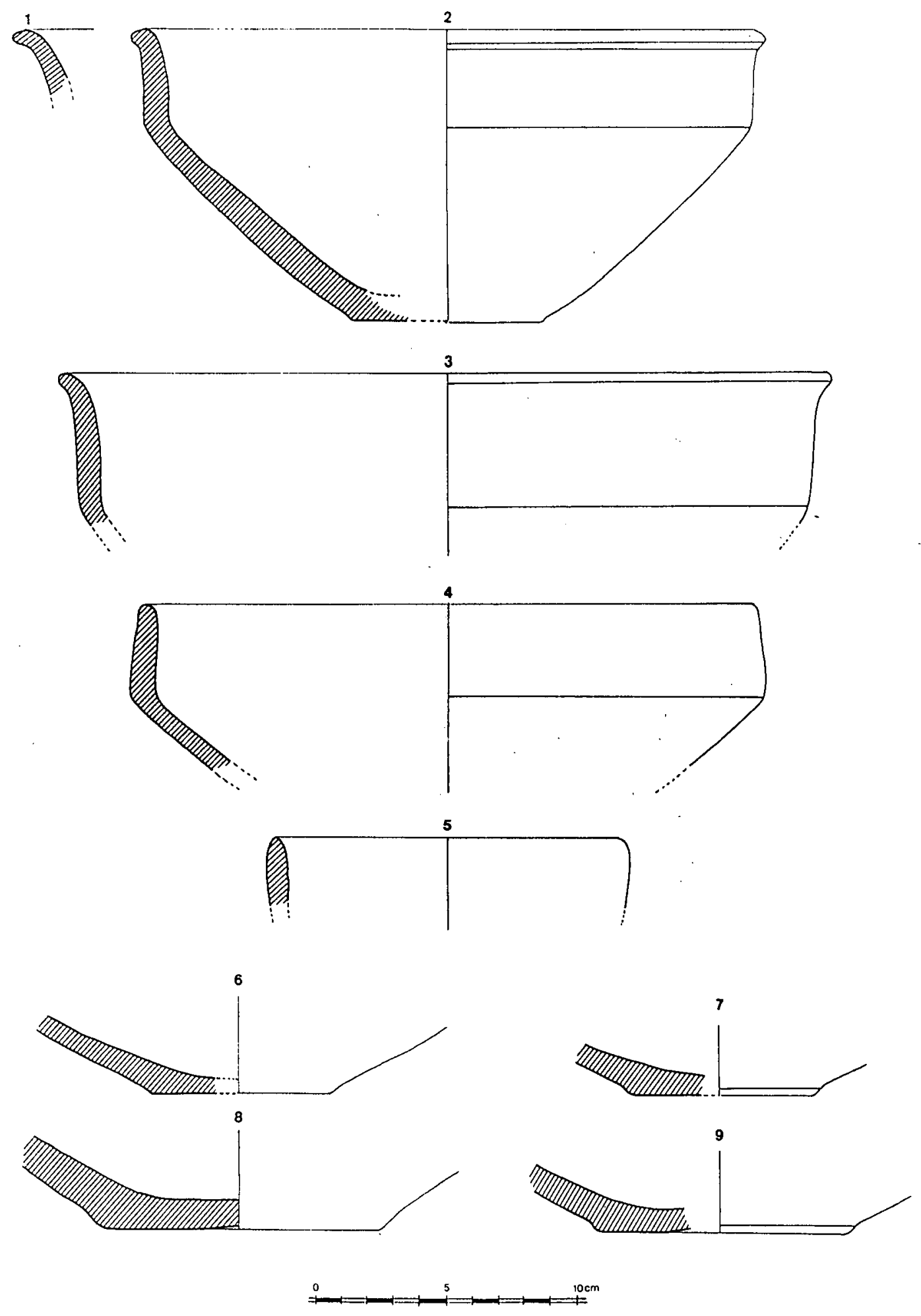

Fig. 9: El Trobal. Cerámica gris. Platos (1-7) y cuencos (8-11). 

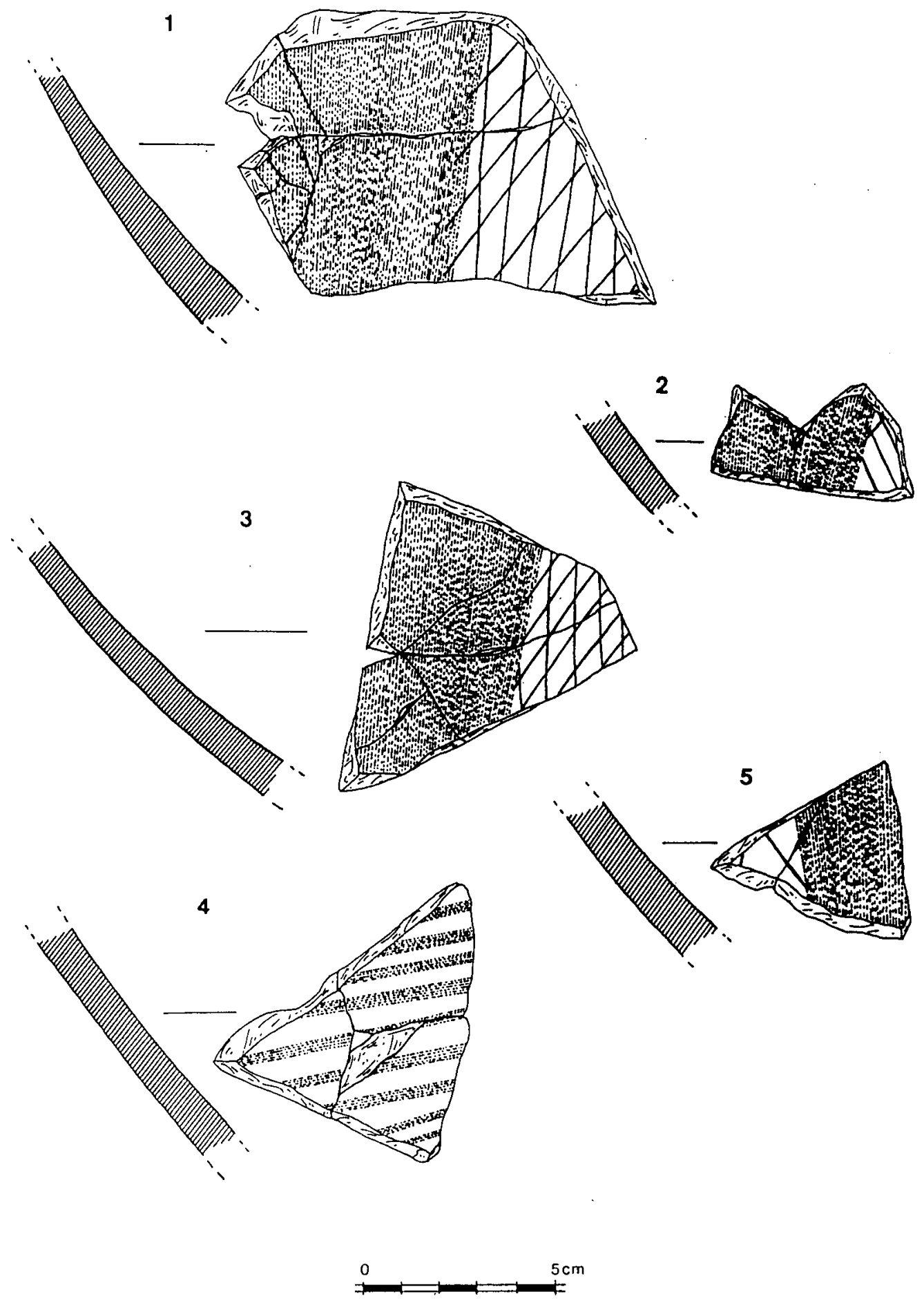

Fig. 10: El Trobal. Cerámica gris. Galbos con decoración interior bruñida. 

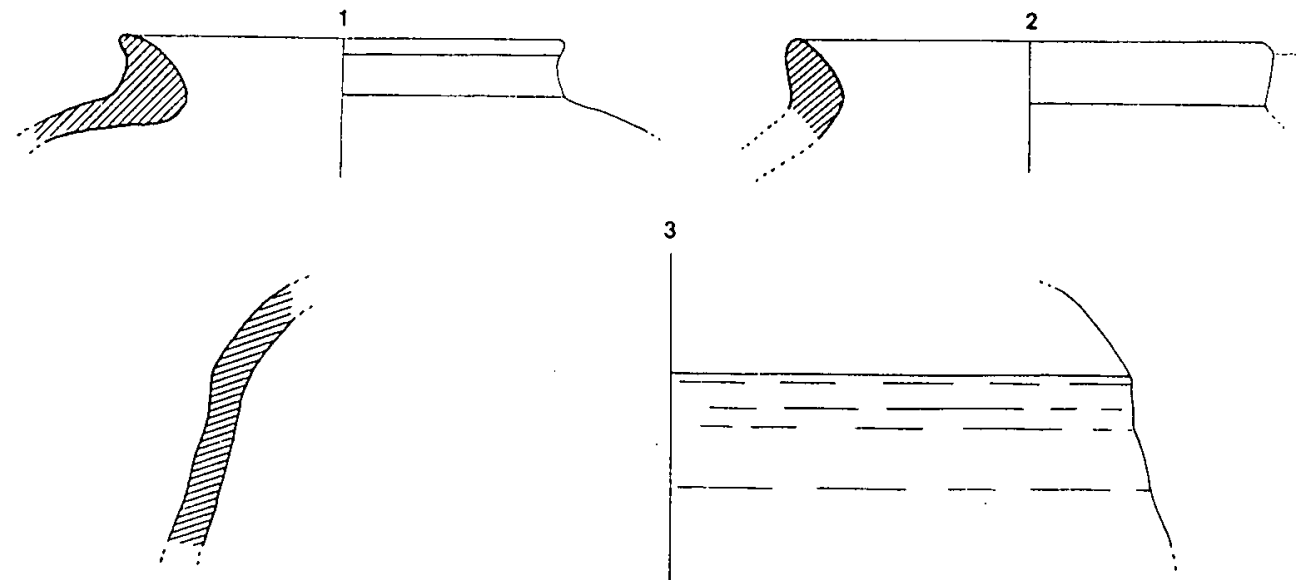

3
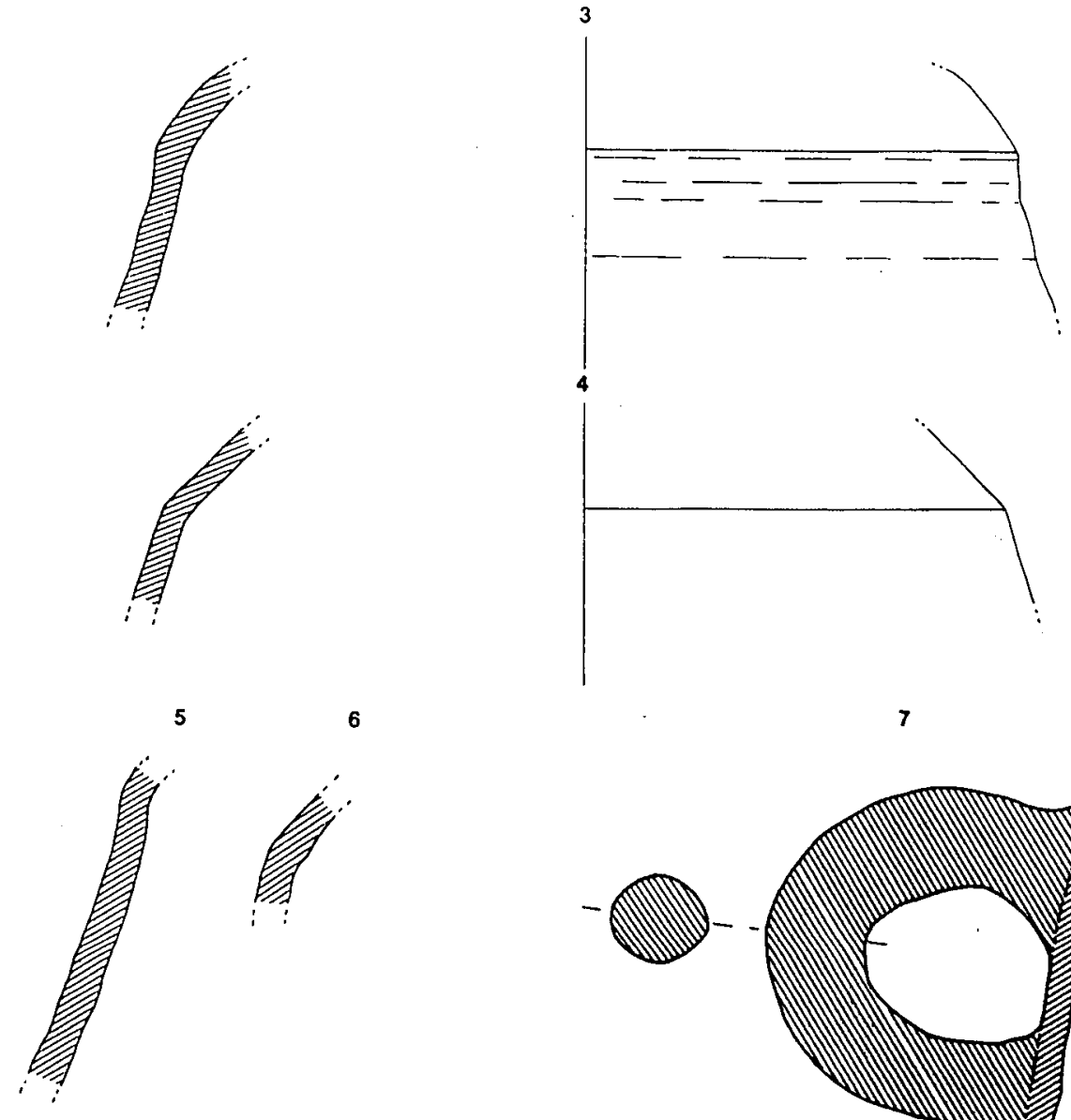

6
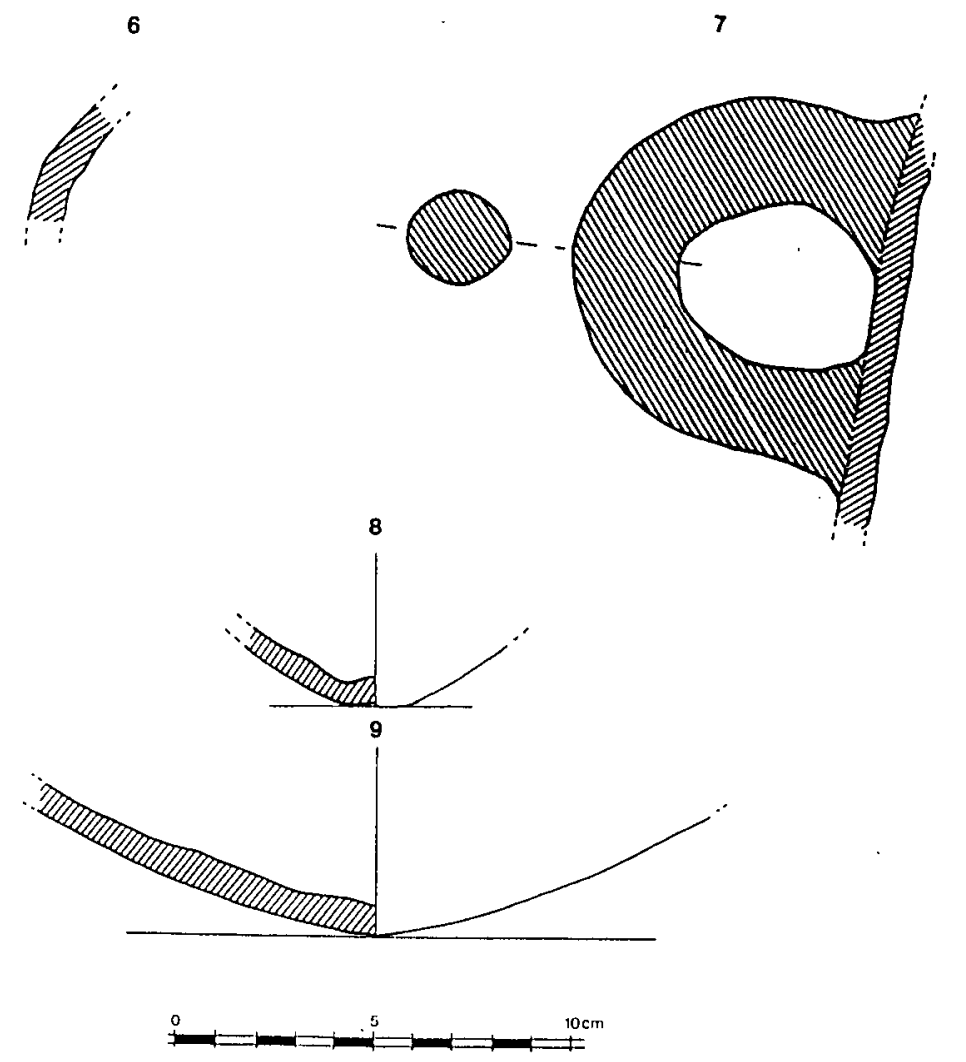

Fig. 11: El Trobal. Cerámica a torno. Ánforas. 

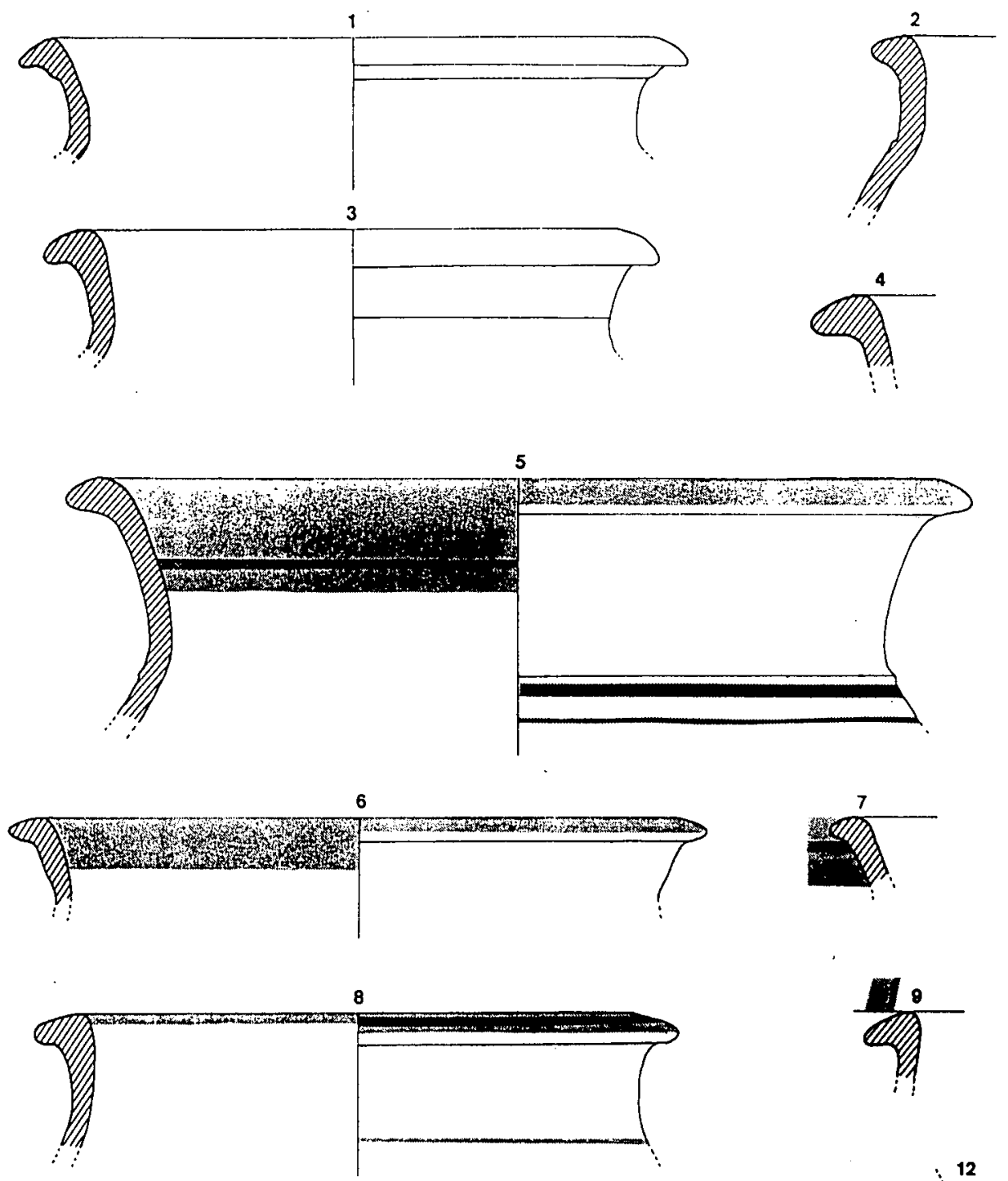

10

11
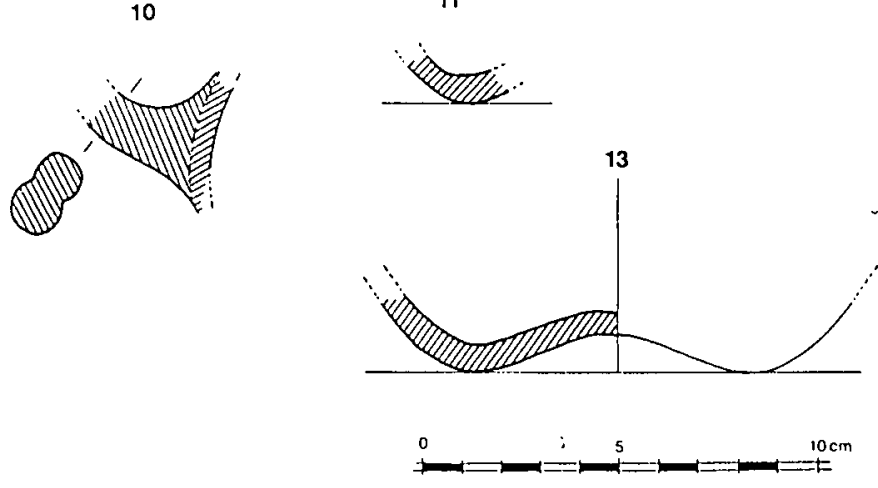

Fig. 12: El Trobal. Cerámica a torno. Vasos. 

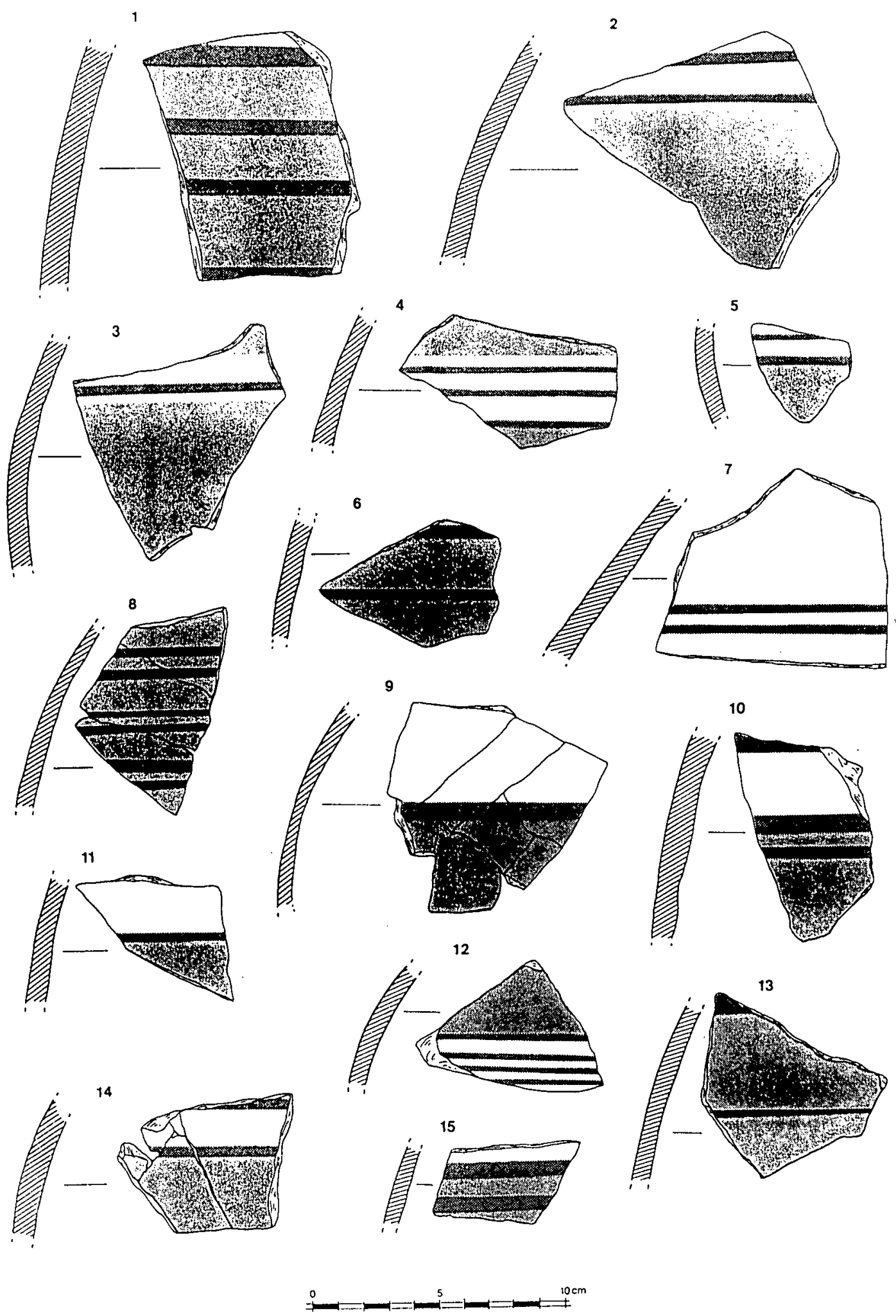

Fig. 13: El Trobal. Cerámica a torno. Galbos con decoración exterior pintada. 

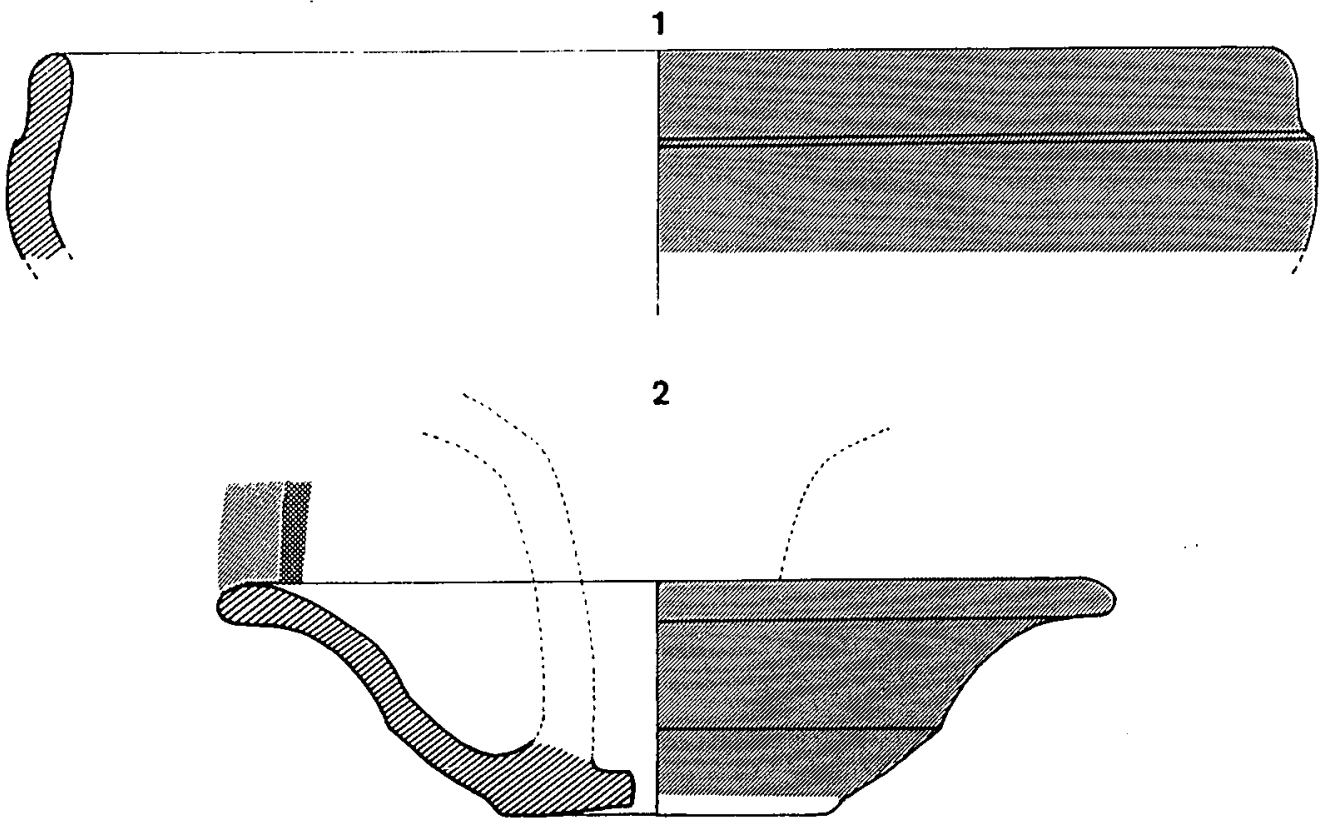

3
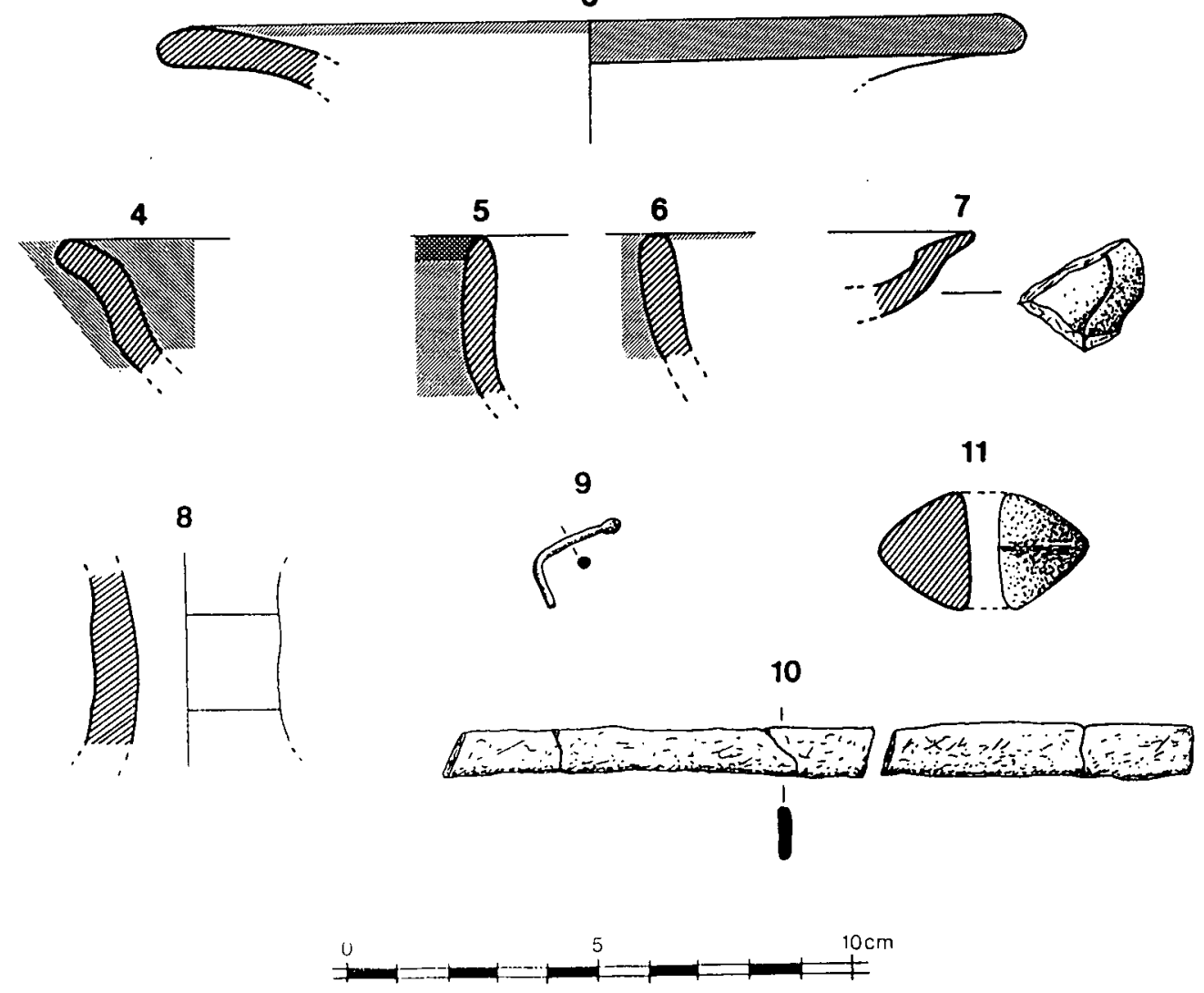

Fig. 14: El Trobal. Cuencos (1,5 y 6), quemaperfuemes (7), plato de borde concavo (4), lucerna (7), soporte (8), fusayola (11) y elementos metálicos $(9$ y 10$)$. 

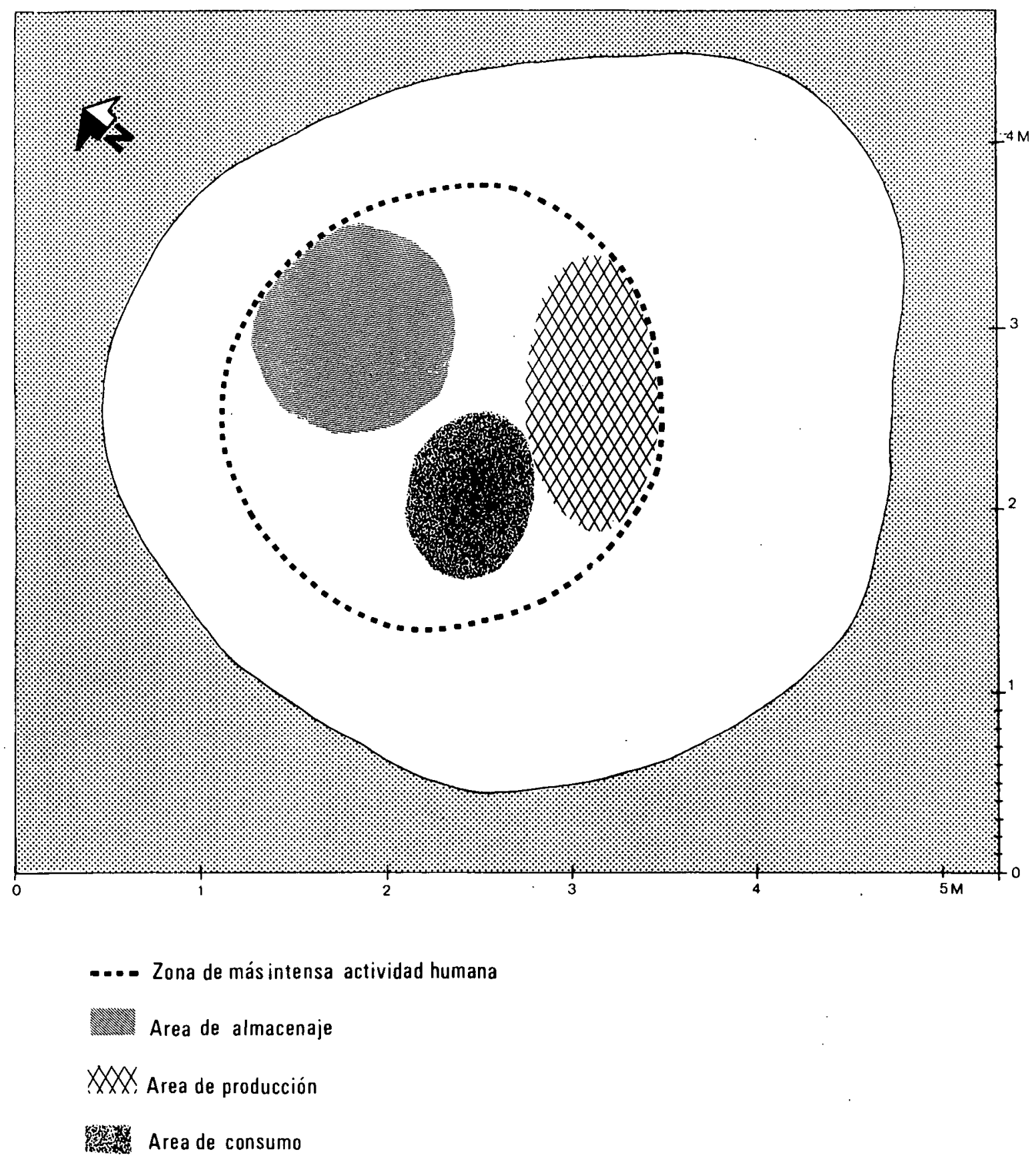

Fig. 15: El Trobal. Posibles áreas funcionales dentro del fondo de cabaña. 


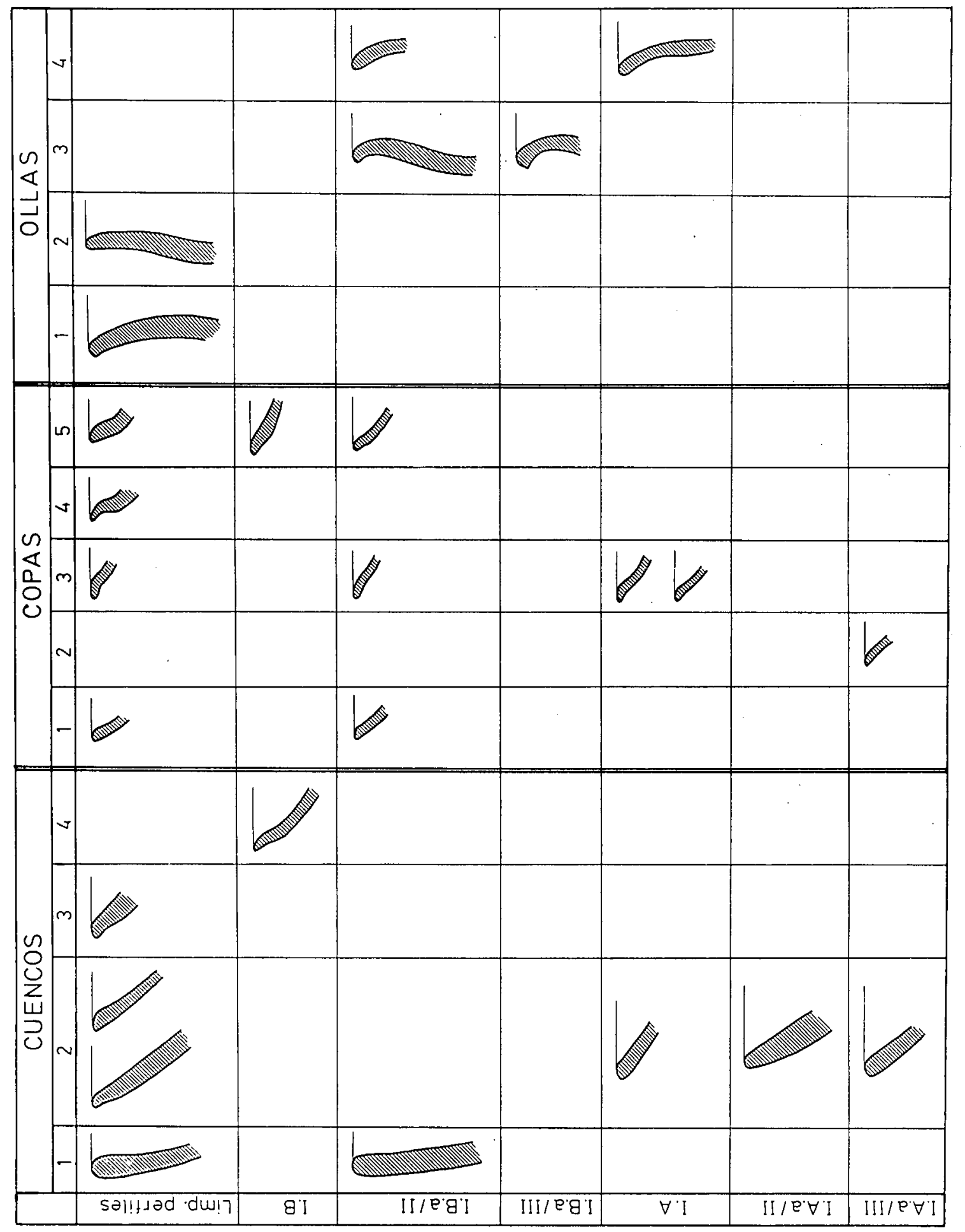




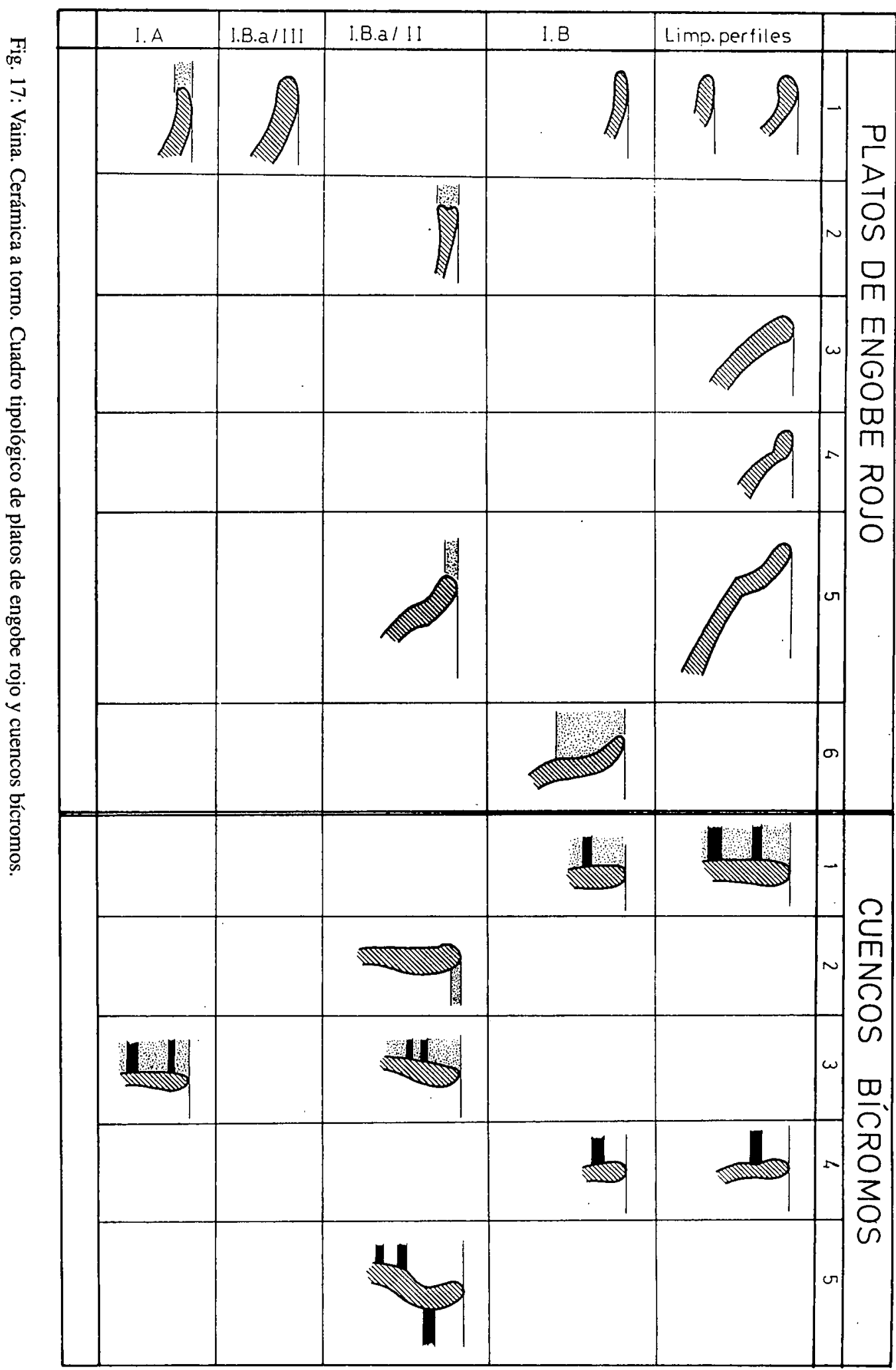




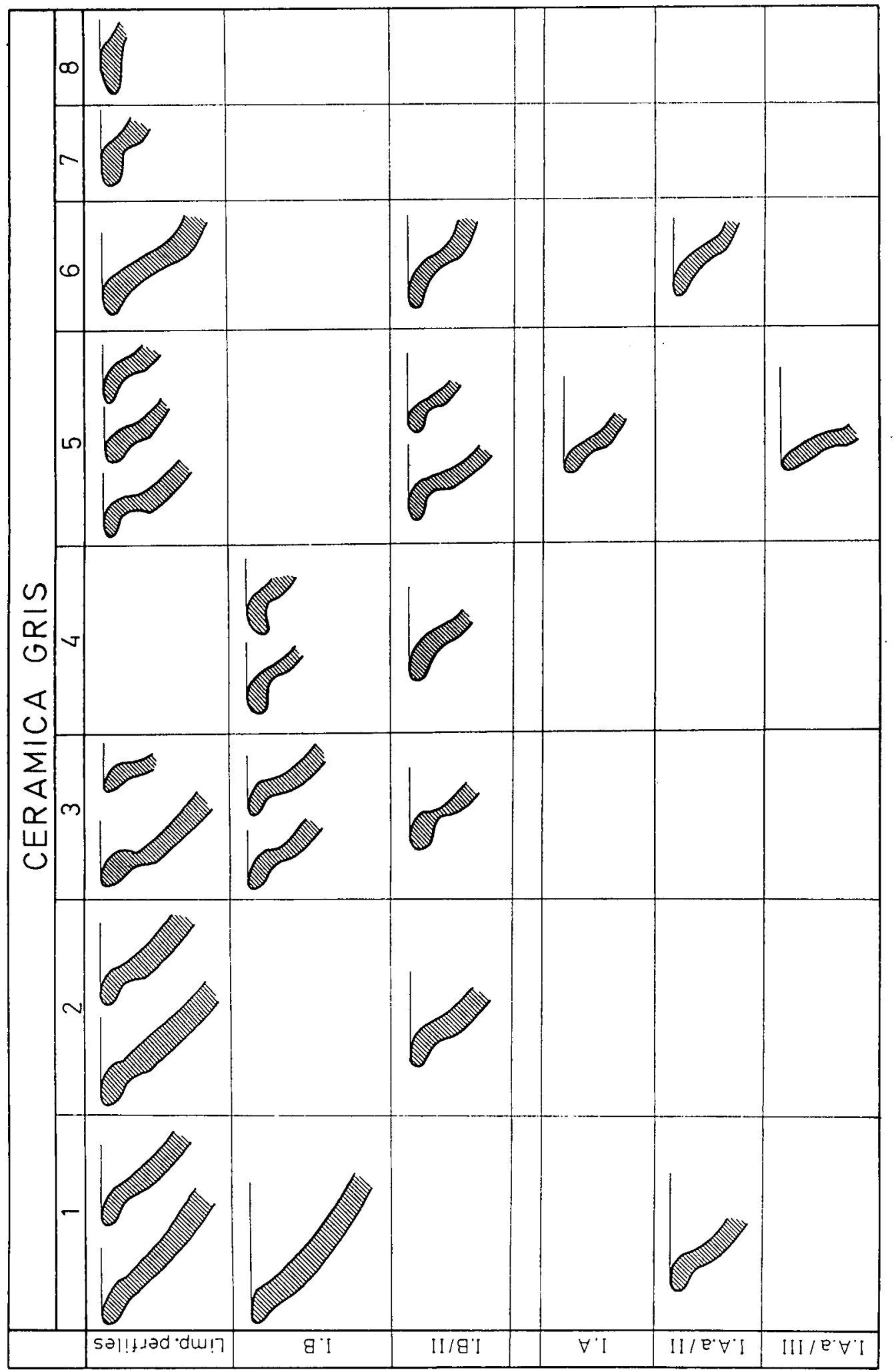

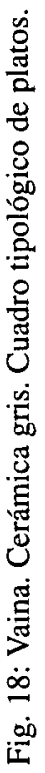




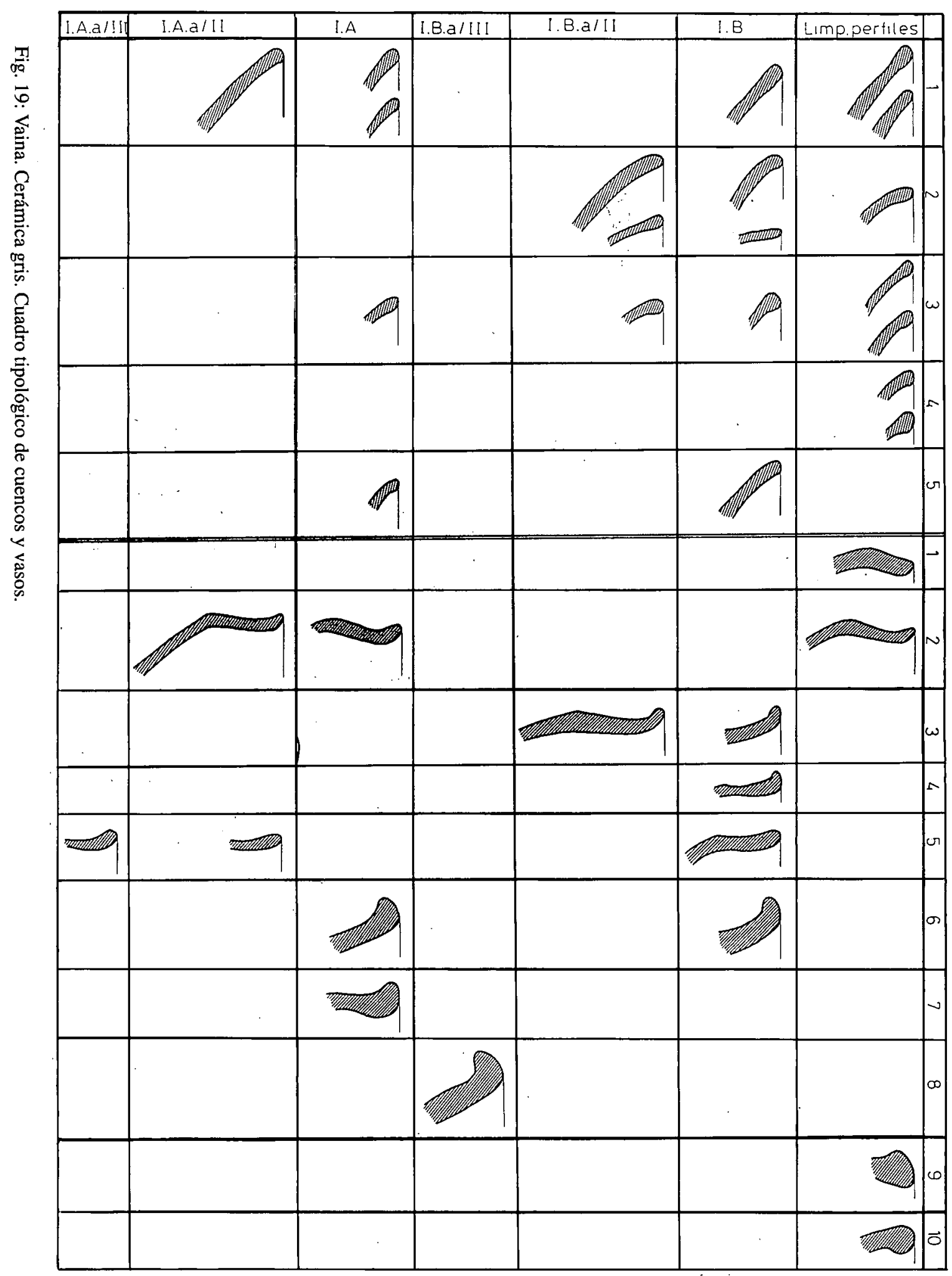




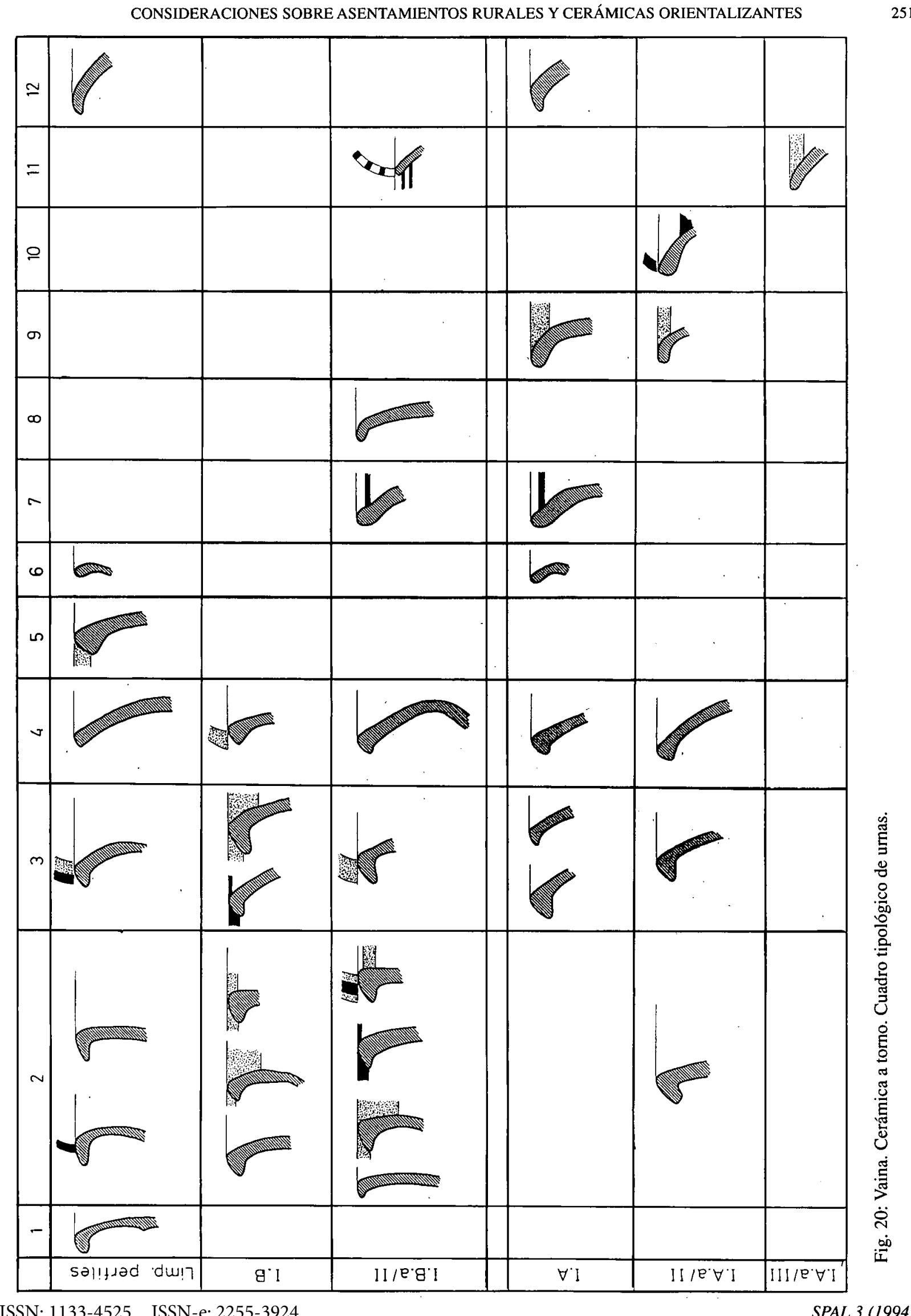

ISSN: 1133-4525 ISSN-e: 2255-3924

http://dx.doi.org/10.12795/spal.1994.i3.08 


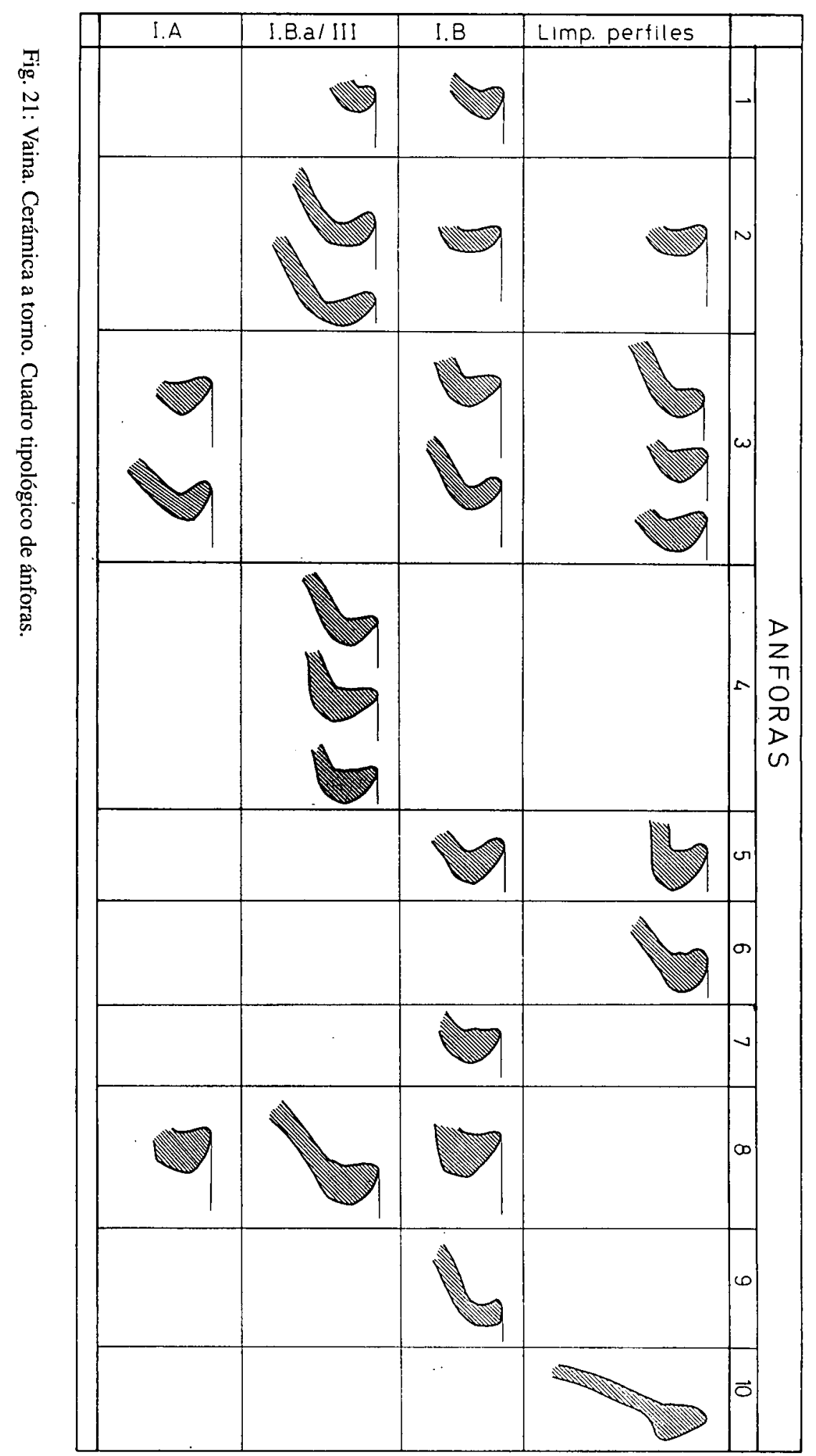



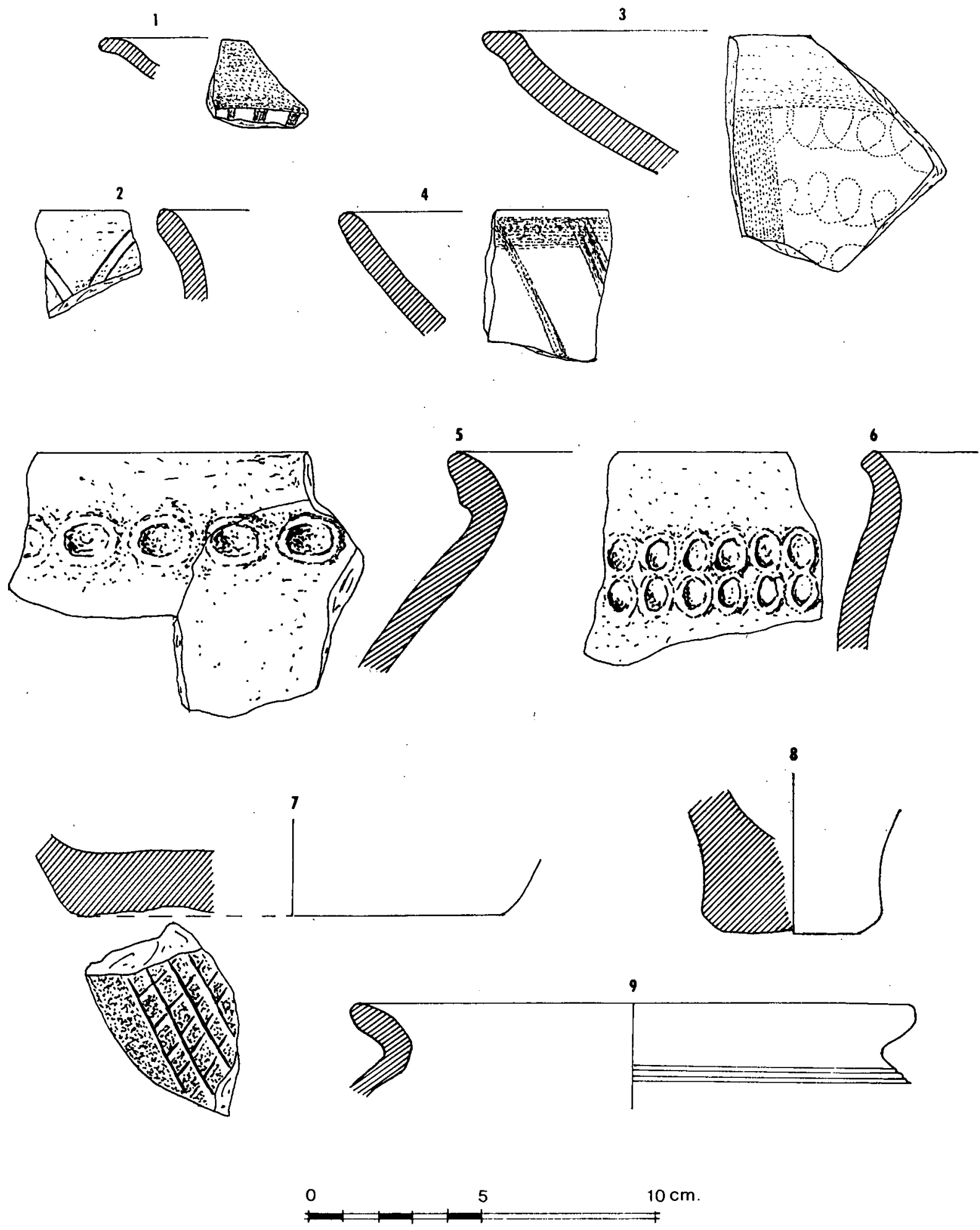

Fig. 22: Baina. Decoración bruñida (1, 3 y 4), incisa a mano (2), digitaciones (5-6), acanaladuras (7), ánfora (8) e incisa a torno (9). 


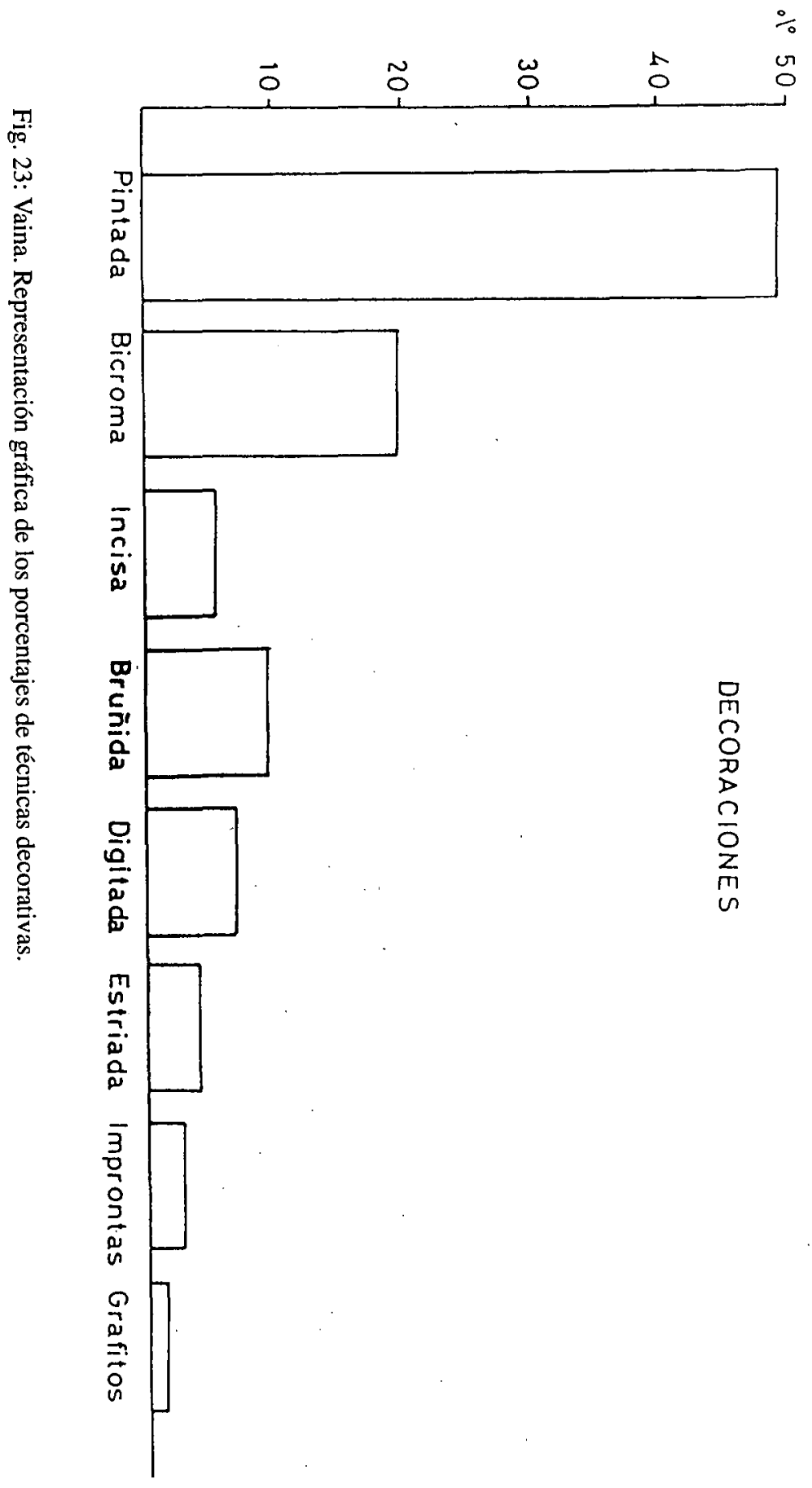


INVENTARTO DE WATERIALES DE EL TROBAL

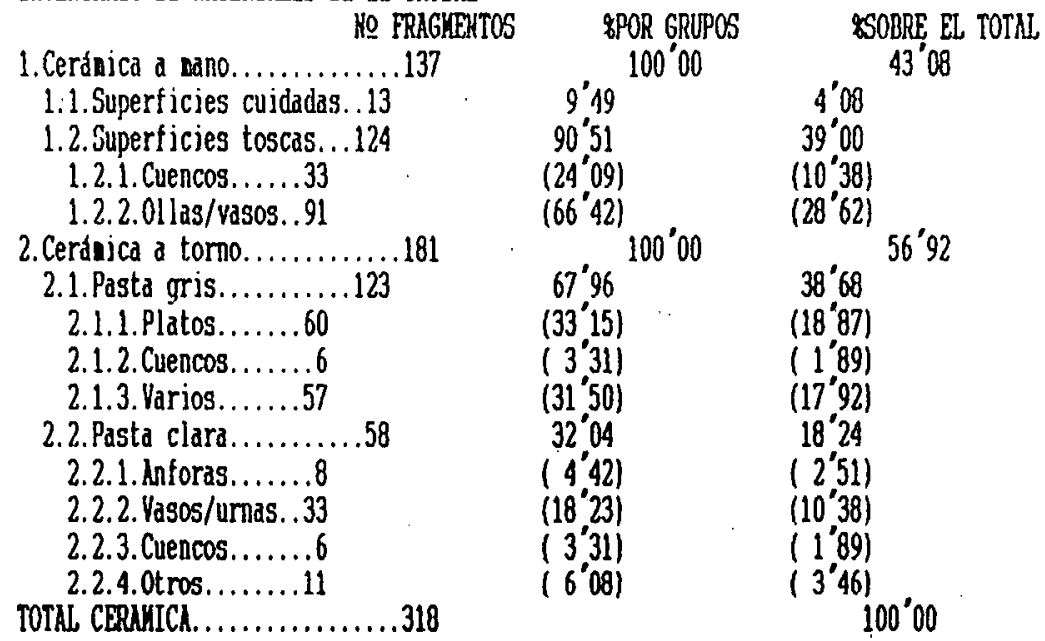

\section{INVENTARIO DE MATERILLES DE BAIM}

\begin{tabular}{|c|c|c|}
\hline 1 Cerácica a mo PRIGTEVTOS & $\begin{array}{l}\text { SPOR GRUPOS } \\
100^{\circ} 00\end{array}$ & $\begin{array}{l}\text { 25OBRE EL TOTAL } \\
10^{\circ} 93\end{array}$ \\
\hline 1.1.Copas................. & $33^{\prime} 33$ & $3^{\prime} 64$ \\
\hline 1.2.Cuencos............ & $42^{\circ} 42$ & $4^{\prime} 64$ \\
\hline 1.3.01las............. & $24^{\prime} 24$ & 2.65 \\
\hline 2. Cerdaica a torno...... & $100^{\prime} 00$ & 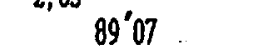 \\
\hline 2.1.Pasta gris......... & $37^{\prime} 55$ & $33^{\circ} 44$ \\
\hline 2.1.1.Platos......33 & $\left(12^{\prime} 27\right)$ & $\left(10^{\circ} 92\right)$ \\
\hline 2.1.2. Cuencos......33 & $\left(12^{\prime} 27\right)$ & $\left(10^{\circ} 92\right)$ \\
\hline 2.1.3.Pateras......20 & $\left(7^{\circ} 43\right)$ & $\left(6^{\circ} 62\right)$ \\
\hline 2.1.4. Varios.......15 & ( 5 '58) & ( (4'97) \\
\hline 2.2. Bngobe Rojo..........11 & 408 & $j^{\circ} 64$ \\
\hline 2.3.ई. abiertas bicron.....8 & 297 & 265 \\
\hline 2.4. Anforas ............26 & $9^{\prime} 66$ & $8^{\prime} 61$ \\
\hline 2.5.Umas..............54 & $20^{\circ} 07$ & $17^{\prime} 88$ \\
\hline 2.6.01las. & $6^{6} 69$ & $5^{\prime} 96$ \\
\hline 2.7. Otros..... & $18^{\prime} 95$ & $16^{\prime} 87$ \\
\hline TOTAL CERAUICA............. & & $100^{\circ} 00$ \\
\hline
\end{tabular}

INVEMTARIO DE MATERIALES. FOHDO I.1 SAN BARTOLOYIE

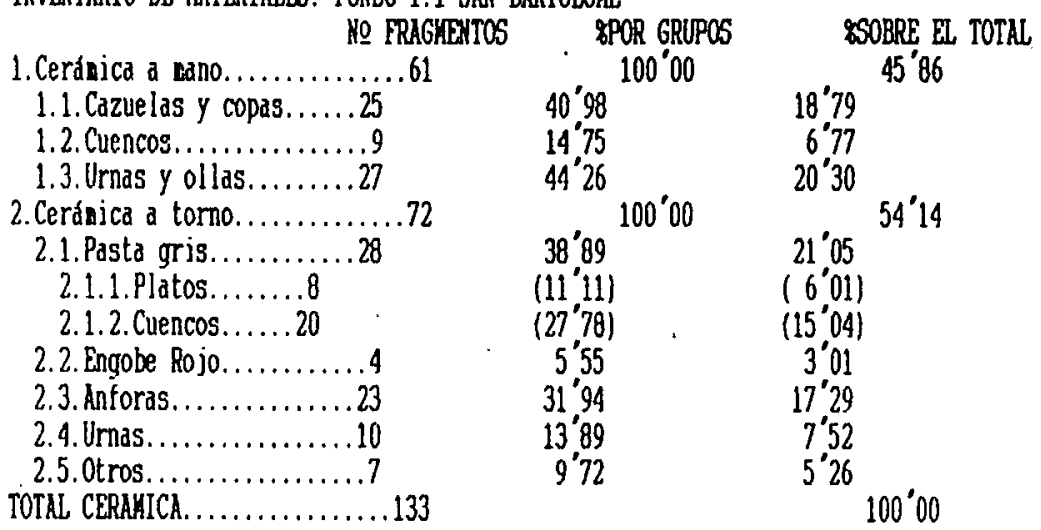

Fig. 24: Estadística de materiales procedentes de los yacimientos estudiados. 


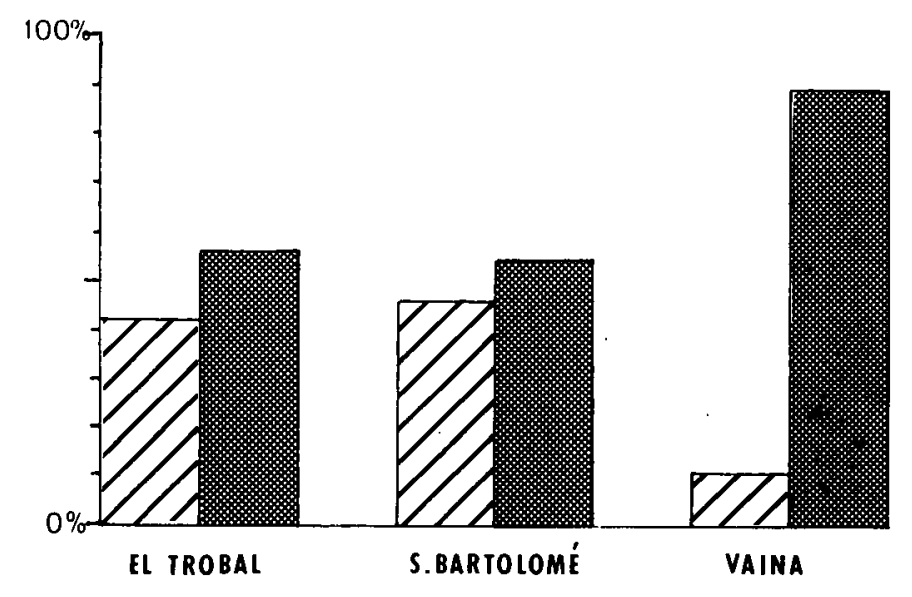

\section{Z Cerámica a mano CERÁMICA A TORNO}

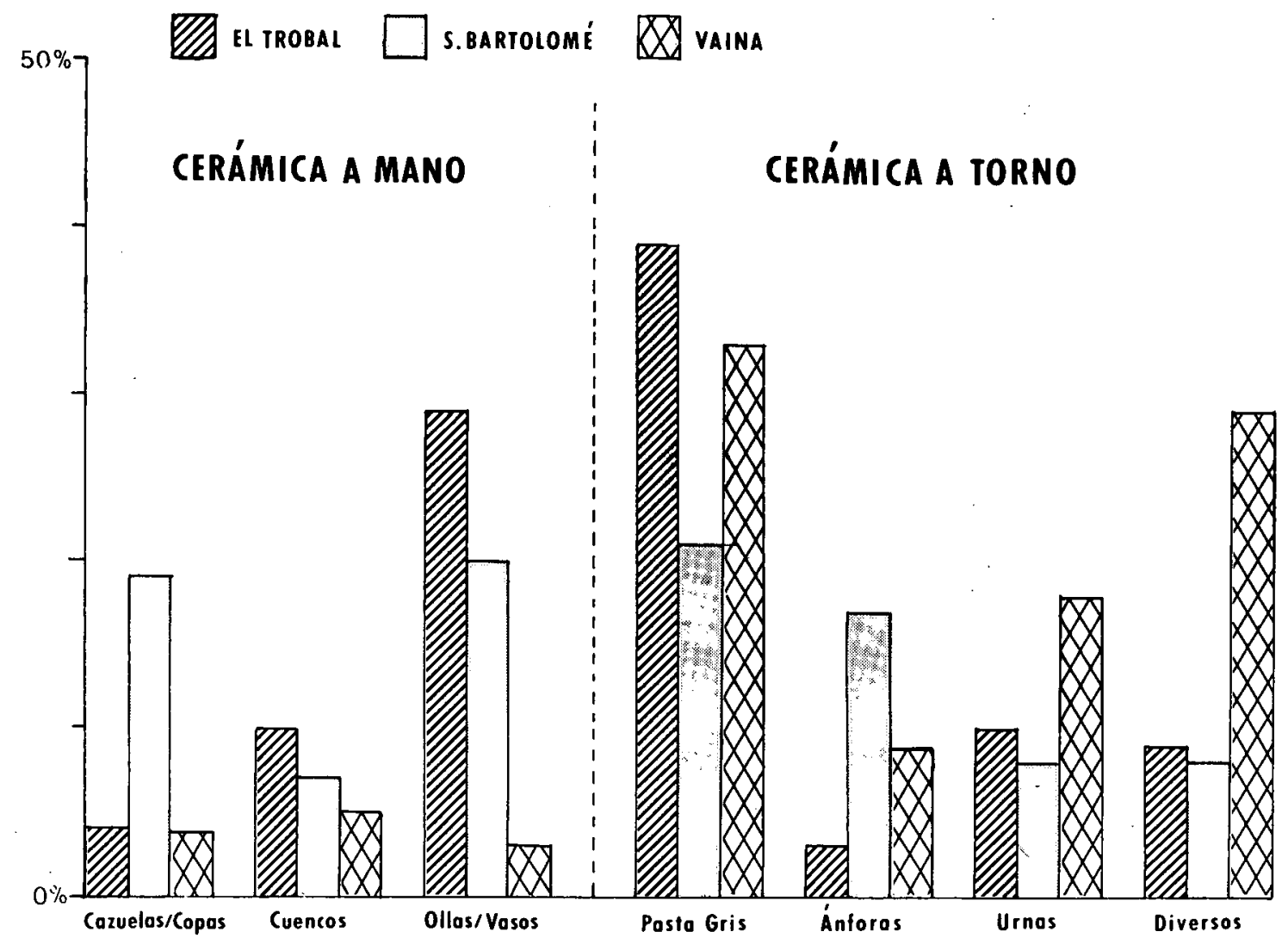

Fig. 25: Representación gráfica de los porcentajes cerámicos de los yacimientos estudiados. 